\title{
Wykorzystanie technik sztucznych sieci neuronowych do predykcji wybranych parametrów jako uzupełnienia zbioru danych wejściowych w konstrukcji modeli parametrycznych 3D
}

\author{
The use of artificial neural network techniques to predict selected parameters as \\ a supplement to the input data set in the construction of 3D parametric models
}

\author{
Weronika Kaczmarczyk ${ }^{1}$, Andrzej Brodzicki ${ }^{2}$ \\ ${ }^{1}$ Instytut Nafty i Gazu - Państwowy Instytut Badawczy \\ ${ }^{2}$ Akademia Górniczo-Hutnicza im. St. Staszica w Krakowie
}

\begin{abstract}
STRESZCZENIE: W artykule przedstawiono możliwości wykorzystania sztucznych sieci neuronowych (SSN) do predykcji parametrycznej w profilach otworów wiertniczych, której zastosowanie uzupełniło zestaw informacji we wszystkich otworach wiertniczych zlokalizowanych w obrębie analizowanego obszaru. Zaprezentowana w artykule metodologia może być użyta w przypadku braku możliwości specjalistycznej interpretacji krzywych geofizyki wiertniczej, uzupełniającej brakujące dane. Zestaw wykorzystanych w pracy danych obejmował rozwiązania w profilach 10 otworów wiertniczych, z których cztery otwory charakteryzowały się pełnym zestawem danych analizowanych w ramach niniejszego artykułu, obejmujących prędkość fali podłużnej, porowatość efektywną, nasycenie węglowodorami, moduł Younga i współczynnik Poissona. Wykorzystując technikę działania sztucznych sieci neuronowych, przeprowadzono predykcję brakujących informacji, bazując na relacjach pomiędzy analizowanymi parametrami w otworach, gdzie estymowane dane były dostępne. W ostatnich latach obserwuje się dynamiczny rozwój technologii szeroko pojętego uczenia maszynowego (ang. machine learning) i tak zwanej sztucznej inteligencji. Niewiele pozostaje dziedzin nauki, w których nie miałyby one zastosowania. Tak jest również w branży naftowo-gazowniczej. Parametr nasycenia węglowodorami, pomimo wyzwań, jakie niesie za sobą interpretacja tego parametru, również został poddany próbie estymacji, potwierdzając niskimi wartościami korelacji pomiędzy analizowanymi parametrami, że wymaga zdecydowanie bardziej zaawansowanych prac o indywidualnym charakterze. Wyniki predykcji parametrycznej, poddane wcześniej walidacji poprzez charakterystykę parametrów R (różnica pomiędzy wartością rzeczywistą a estymowaną) i RMSE (pierwiastek błędu średniokwadratowego), zostały w kolejnym kroku zaaplikowane w procesie modelowania przestrzennego wszystkich analizowanych parametrów. Finalnie, w celu wizualizacji różnic pomiędzy wykorzystaniem niepełnego i po części estymowanego zestawu danych w analizie przestrzennej, zaprezentowano mapę średnich wartości wybranego parametru w obrębie analizowanego interwału stratygraficznego. Tak przygotowany zestaw danych pozwolił na bardziej wiarygodne odtworzenie przestrzenne rozkładu parametrów istotnych w kontekście charakterystyki złoża węglowodorów, na podstawie którego w kolejnych etapach możliwa jest wiarygodniejsza ocena potencjału złożowego analizowanego obiektu. Zaprezentowana w artykule metodyka, oparta na rozwiązaniu rzeczywistego problemu badawczego, stanowi alternatywę, dla koszto- i czasochłonnych interpretacji geofizycznych, niekiedy znacznych liczb otworów wiertniczych, szczególnie dla obszarów charakteryzujących się relatywnie niewielką przestrzenną zmiennością i złożonością tektoniczną. Warunkiem jest dostępność interpretacji danych geofizyki wiertniczej w co najmniej kilku otworach stanowiącej wzorzec dla odtworzenia zmienności badanego parametru/parametrów w pozostałych profilach otworów wiertniczych.
\end{abstract}

Słowa kluczowe: predykcja 1D, sieci neuronowe, estymacja parametryczna, modelowanie 3D, charakterystyka złoża węglowodorów.

ABSTRACT: The article presents the possibilities of using artificial neural networks for parametric prediction in borehole profiles, the application of which supplemented the set of information in all boreholes located within the analyzed area. The approach presented in the article will be used when there is no possibility of specialized interpretation of the drilling geophysics curves, supplementing the missing data. The set of data used in the study included solutions in the profiles of 10 boreholes, four of which were characterized by the availability of the full data set analyzed in this article, including compressional wave velocity, effective porosity, hydrocarbon saturation, Young's modulus and Poisson's ratio. Using the technique of the operation of artificial neural networks, a prediction of missing information was carried out based on the relationships between the analyzed parameters in the wells, where the estimated

Autor do korespondencji: W. Kaczmarczyk, e-mail: weronika.kaczmarczyk@inig.pl

Artykuł nadesłano do Redakcji: 27.01.2021 r. Zatwierdzono do druku: 07.07.2021 r. 
data was available. In recent years, there has been a dynamic development of machine learning technology and the so-called artificial intelligence. There are very few fields of science in which they find no application. The hydrocarbon saturation parameter, despite the challenges posed by the interpretation of this parameter, was also subjected to an estimation attempt, confirming the low correlation values between the analyzed parameters and requiring much more advanced work of an individual nature. The results of parametric prediction, previously validated by characterizing the R and RMSE parameters, were applied in the next step in the spatial modeling process of all analyzed parameters. Finally, as part of the visualization of the differences between the use of an incomplete and partially estimated data set in spatial analysis, a map of mean values of the selected parameter within the analyzed interval was presented. The set of data prepared in this way allowed for a more reliable spatial reconstruction of the distribution of parameters important in the context of the characteristics of the hydrocarbon reservoir, on the basis of which, in the subsequent stages, it is possible to more fully assess the deposit potential of the analyzed object. The methodology presented in the article, supported by a real case study, is an alternative to geophysical interpretations that require financial and time resources, sometimes large numbers of boreholes, especially for areas characterized by relatively low spatial variability and tectonic complexity. The condition is the availability of the interpretation in at least several boreholes, constituting a pattern for recreating the variability of the tested parameter / parameters in the remaining profiles of the boreholes.

Key words: 1D prediction, artificial neural network, parametrical estimation, 3D modeling, hydrocarbon reservoir characterization.

\section{Wprowadzenie}

Wiarygodność odtwarzanych w przestrzeni parametrów złożowych (takich jak porowatość, zailenie, przepuszczalność, nasycenie mediami złożowymi, szczelinowatość) jest o tyle większa, o ile większa jest ilość, możliwie jak najlepszej jakości, wiarygodnych danych wykorzystanych w konstrukcji odtwarzanych rozkładów przestrzennych. Dotyczy to zarówno danych otworowych (laboratoryjnych, krzywych geofizyki wiertniczej i ich interpretacji), jak i sejsmicznych (wyników przetwarzań wolumenu sejsmicznego, interpretacji strukturalnych, inwersji sejsmicznych, atrybutów sejsmicznych), których pozyskanie generuje nakłady czasowe i finansowe. Celem redukcji kosztów niekiedy pomijane są istotne pomiary charakteryzujące złoże. W związku z tym szerzej rozwijane i wykorzystywane są metody statystyczne, jak również coraz chętniej stosowane są techniki sztucznej inteligencji (szczególnie głębokie sieci neuronowe - ang. deep neural network) dla uzupełnienia brakujących informacji pozwalających lepiej zrozumieć badany ośrodek geologiczny. W artykule przedstawiono zagadnienie predykcji wybranych (brakujących w posiadanym zestawie danych) informacji dotyczących przebiegu w profilu kilku otworów wiertniczych następujących parametrów: prędkości fali poprzecznej, porowatości efektywnej, nasycenia węglowodorami, modułu Younga, współczynnika Poissona.

Uzupełnienie braków informacji pozwoliło w sposób bardziej wiarygodny odtworzyć charakter przestrzenny poszczególnych parametrów, co może znacząco wpłynąć na otrzymany finalnie obraz złoża. Dobór parametrów biorących udział w procesie predykcji obejmował jednakowy zestaw danych wejściowych, niemniej jednak w zależności od celu (tj. jaki parametr jest estymowany) wybierane powinny być indywidualnie zestawy pomiarów wzajemnie od siebie zależnych.

Pełne interpretacje krzywych geofizyki wiertniczej są najbardziej pożądaną informacją, niemniej jednak w pewnych przypadkach alternatywę stanowić mogą wyniki predykcji uzyskane sztucznymi sieciami neuronowymi (SSN), co zostało zaprezentowane w niniejszym artykule. Przedmiotową analizę poprowadzono w utworach dolomitu głównego na obszarze półwyspu Grotowa, w którym to interwale stwierdzono akumulacje węglowodorów.

\section{Obszar analizy}

Analizowany w pracy obiekt Grotów wchodzi w skład zespołu złóż Lubiatów-Międzychód-Grotów i stanowi pułapkę o charakterze litologicznym lub litologiczno-strukturalnym w utworach dolomitu głównego Ca2 (Pikulski, 2004). Obszar analizy położony jest w północnej części półwyspu Grotowa na obszarze platformy węglanowej, na północny wschód od struktury Międzychód (rys. 1). Obiekt ten paleogeograficznie związany jest z równią platformową (Jaworowski i Mikołajewski, 2007). W jej obrębie panowały warunki płytkowodne, gdzie występowały zarówno strefy wysoko- jak i niskoenergetyczne (Czekański et al., 2010). Bazując na obserwacjach sedymentologicznych i petrograficznych, można zauważyć, że w rejonie Grotowa mamy do czynienia ze znacznym zróżnicowaniem mikrofacjalnym, będącym efektem zmiennych warunków sedymentacji. Miąższość utworów dolomitu głównego zmienia się w zakresie od 33,5 m do $80 \mathrm{~m}$. Reprezentowane są one głównie przez wakstony, pakstony, grainstony onkoidowo-ooidowo-intraklastrowe oraz bandstony (Pikulski, 2004). Pomimo stwierdzonych wysokich porowatości (sięgających nawet powyżej 20\%) utwory te charakteryzują się często niskimi przepuszczalnościami - z wyjątkiem stref cechujących się występowaniem szczelinowatości. Przestrzeń porową w głównej mierze uzupełnia cement węglanowy, anhydryt oraz minerały ilaste (Pikulski, 2004). Analizowany obszar rozpoznany jest dziesięcioma otworami wiertniczymi oraz zdjęciem sejsmicznym 3D, które to dane zostały przeanalizowane pod kątem założonego w artykule celu. 


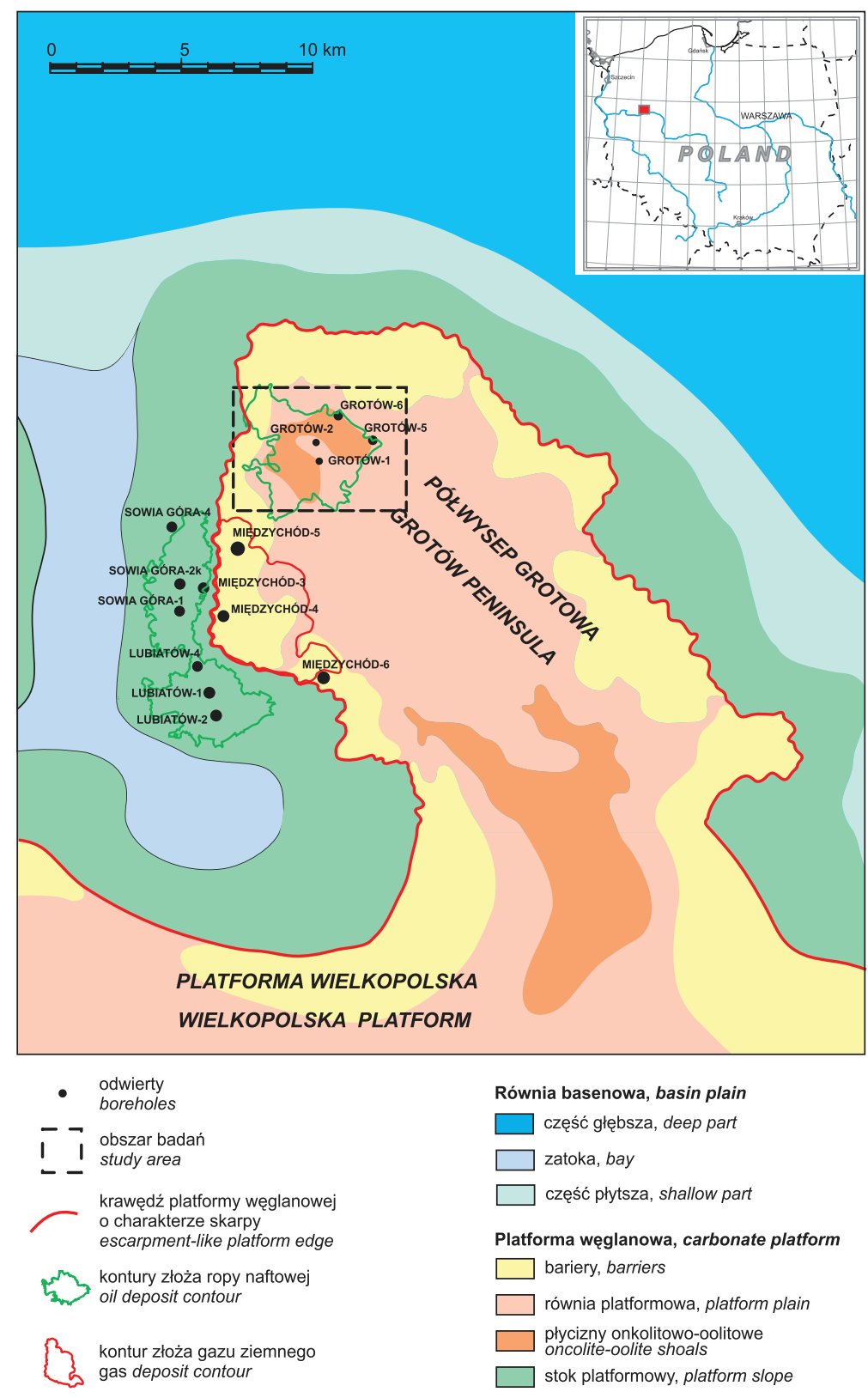

Rys. 1. Lokalizacja obszaru badań (czarny przerywany poligon) oraz analizowanych otworów wiertniczych na tle mapy paleogeograficznej dolomitu głównego obejmującej półwysep Grotowa (Wagner, 2004)

Fig. 1. Location of the analyzed area (black dashed polygon) and the boreholes against the paleogeographic map of the Main Dolomite in the area of Grotów Peninsula, Poland (Wagner, 2004)
Szczegółową charakterystykę litologiczno-petrofizyczną utworów dolomitu głównego dotyczącą omawianego obszaru opisano w wielu pracach (m.in. Mikołajewski, 2004; Pikulski, 2004; Kaźmierczuk et al., 2006; Jaworowski i Mikołajewski, 2007; Semyrka et al., 2008, 2015; Kwolek i Mikołajewski, 2010; Krogulec et al., 2020).

\section{Dane i metody}

W obrębie analizowanego obszaru dysponowano danymi z 10 otworów wiertniczych. Pełen zakres danych istotnych z punktu widzenia założonego celu, omówionego we wstępie artykułu, dostępny był jedynie w czterech $\mathrm{z}$ nich (G-1, G-2, G-8H, G-9K). Z całego zestawu parametrów wyłącznie impedancja akustyczna (AI), będąca iloczynem prędkości fali podłużnej oraz gęstości, była dostępna we wszystkich 10 odwiertach. Eliminacja braków odnoszących się do pozostałych parametrów w poszczególnych odwiertach jest celem obranym w niniejszym artykule. Estymacji niedostępnych wartości parametrów dokonano za pomocą sieci neuronowych, których zasada działania została szerzej omówiona w kolejnym rozdziale.

Na rysunku 2 zaprezentowano zestaw danych z otworu, w którym dostępne były wszystkie z parametrów charakteryzujących analizowany interwał dolomitu głównego, ograniczony od stropu czerwoną i od spągu niebieską linią. Niskie wartości impedancji akustycznej (AI), modułu Younga (YD), prędkości fali Stoneleya (Vstonley) oraz wysokie wartości porowatości (PHI), porowatości efektywnej (PHIE), nasycenia węglowodorami (1-Sw) sugerują interwał o polepszonych własnościach zbiornikowych nasycony węglowodorami.

Tabela 1. Dostępność danych otworowych w profilu utworów dolomitu głównego w poszczególnych otworach

Table 1. Availability of the well data in the Main Dolomite interval in individual boreholes

\begin{tabular}{|c|c|c|c|c|c|c|c|c|c|c|}
\cline { 2 - 11 } \multicolumn{1}{c|}{} & G-1 & G-2 & G-5 & G-6 & G-8H & G-9H & G-4K & G-8K & G-10 & G-12 \\
\hline AI & $\mathrm{X}$ & $\mathrm{X}$ & $\mathrm{X}$ & $\mathrm{X}$ & $\mathrm{X}$ & $\mathrm{X}$ & $\mathrm{X}$ & $\mathrm{X}$ & $\mathrm{X}$ & $\mathrm{X}$ \\
\hline VpVs & $\mathrm{X}$ & $\mathrm{X}$ & - & - & $\mathrm{X}$ & $\mathrm{X}$ & $\mathrm{X}$ & $\mathrm{X}$ & $\mathrm{X}$ & $\mathrm{X}$ \\
\hline PHI & $\mathrm{X}$ & $\mathrm{X}$ & $\mathrm{X}$ & $\mathrm{X}$ & $\mathrm{X}$ & $\mathrm{X}$ & $\mathrm{X}$ & - & $\mathrm{X}$ & $\mathrm{X}$ \\
\hline 1-Sw & $\mathrm{X}$ & $\mathrm{X}$ & $\mathrm{X}$ & $\mathrm{X}$ & $\mathrm{X}$ & $\mathrm{X}$ & - & $\mathrm{X}$ & $\mathrm{X}$ & - \\
\hline PHIE & $\mathrm{X}$ & $\mathrm{X}$ & $\mathrm{X}$ & $\mathrm{X}$ & $\mathrm{X}$ & $\mathrm{X}$ & - & $\mathrm{X}$ & - & - \\
\hline YD & $\mathrm{X}$ & $\mathrm{X}$ & - & - & $\mathrm{X}$ & $\mathrm{X}$ & $\mathrm{X}$ & - & $\mathrm{X}$ & $\mathrm{X}$ \\
\hline POIS & $\mathrm{X}$ & $\mathrm{X}$ & - & - & $\mathrm{X}$ & $\mathrm{X}$ & $\mathrm{X}$ & - & $\mathrm{X}$ & $\mathrm{X}$ \\
\hline Vstonley & $\mathrm{X}$ & $\mathrm{X}$ & - & - & $\mathrm{X}$ & $\mathrm{X}$ & - & - & $\mathrm{X}$ & $\mathrm{X}$ \\
\hline
\end{tabular}




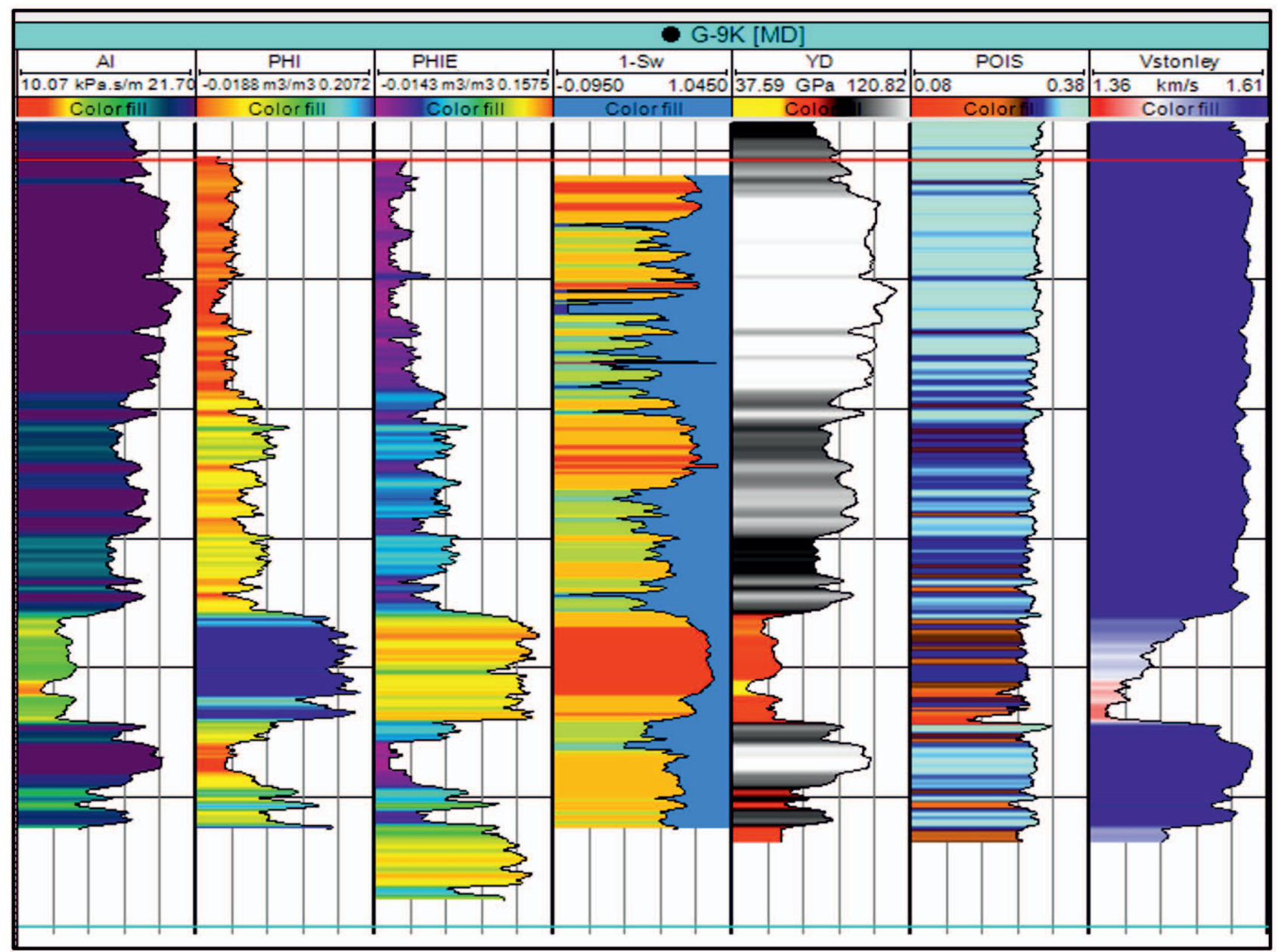

Rys. 2. Zestaw krzywych geofizyki wiertniczej w jednym z otworów, gdzie dostępny był pełen zakres danych

Fig. 2. Set of the well log data from the borehole where the full data set was available

\section{Sieci neuronowe}

Opis stosowanych w tej publikacji metod warto rozpocząć od wyjaśnienia, czym jest uczenie maszynowe, a także czym są głębokie sieci neuronowe (ang. deep neural networks), które stanowią jeden z jego rodzajów (rys. 3).

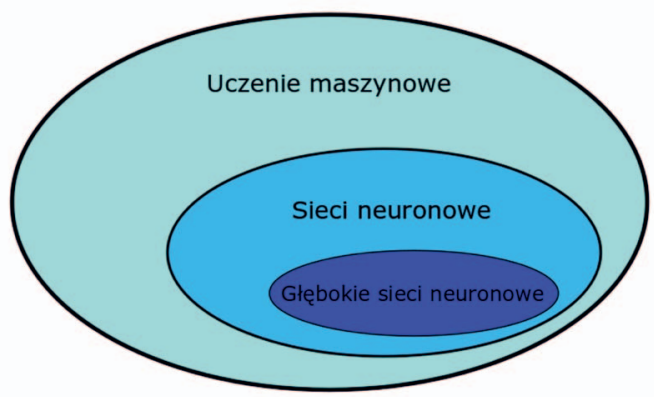

Rys. 3. Sieci neuronowe jako podkategoria uczenia maszynowego Fig. 3. Neural networks as a subcategory of machine learning

Uczenie maszynowe różni się od klasycznego programowania komputerowego relacją, jaka zachodzi między danymi, wynikami i programem. W podejściu klasycznym programista pisze kod wykonujący szereg instrukcji (np. obliczeń matematycznych) na danych wejściowych. W wyniku działania programu otrzymywane są wyniki. Wadą tego podejścia jest konieczność posiadania wiedzy o tym, jakie operacje należy wykonać. Uczenie maszynowe odwraca ten schemat. Mając dane wejściowe i dane wyjściowe, stara się odkryć wzór - nauczyć się relacji, jakie między nimi panują. Ilustruje to rysunek 4 .
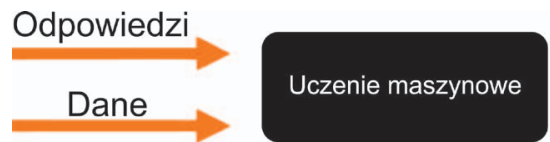

\section{Reguły}

Rys. 4. Ogólna idea działania algorytmów uczenia maszynowego

Fig. 4. Main idea behind machine learning algorithms

Istnieje bardzo duża liczba algorytmów uczenia maszynowego, przeznaczonych do różnych celów. Jedną z podgrup, które zyskały w ostatnich kilku dekadach dużą popularność, są sieci neuronowe. Sieci neuronowe, inspirowane systemem połączeń w ludzkim mózgu (choć tak naprawdę niemające wiele wspólnego z jego działaniem), są techniką modelowania pozwalającą na odwzorowanie skomplikowanych, nieliniowych funkcji. 
Idea ich działania opiera się na połączeniach pomiędzy danymi wejściowymi a punktami pośrednimi - neuronami. W każdym neuronie dane wejściowe mnożone są przez odpowiednie wagi, sumowane, a następnie przeliczane przez funkcję aktywacji. Wynik zwracany przez neuron wykorzystywany jest jako wejście w warstwie następnej i tak dalej. Model pojedynczego neuronu został przedstawiony na rysunku 5.

\section{Schemat działania pojedynczego neuronu}

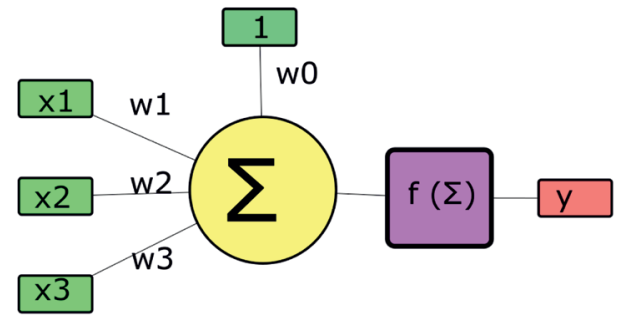

Rys. 5. Model pojedynczego neuronu

Fig. 5. A model of a single neuron

Jednym z elementów, który różnicuje sposób działania danego neuronu, jest funkcja aktywacji. W zależności od pożądanych wyników może to być funkcja liniowa lub nieliniowa, jak sigmoida, tangens hiperboliczny czy popularna w ostatnich latach funkcja ReLU (ang. rectified linear unit). Funkcje te umożliwiają sieciom neuronowym reprezentowanie złożonych przekształceń. Przykładowe wzory i wykresy typowych funkcji aktywacji prezentuje rysunek 6 . Więcej informacji na ich temat można znaleźć w Leksykonie sieci neuronowych (Tadeusiewicz i Szaleniec, 2015).

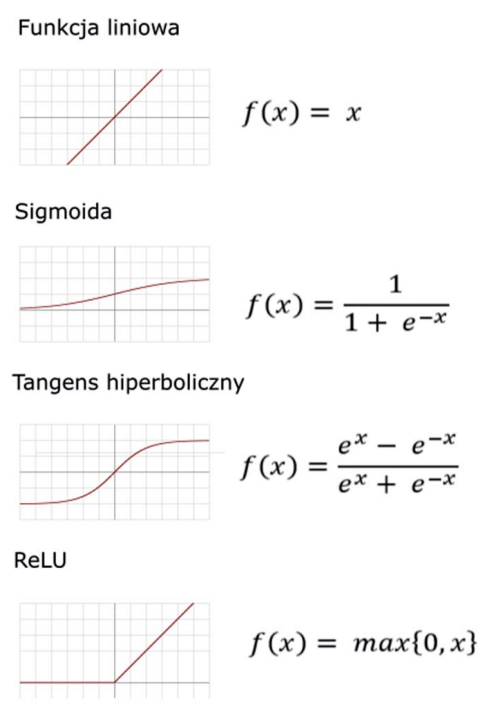

Rys. 6. Przykładowe funkcje aktywacji

Fig. 6. Examples of activation functions

Kluczową cechą wszystkich sieci neuronowych jest uczenie się, polegające na dostrajaniu wag połączeń między neuronami. Używa się w tym celu różnych reguł uczenia. Metody te dzieli się przeważnie na nadzorowane (ang. supervised learning) i nienadzorowane (ang. unsupervised learning), a także rzadziej stosowane półnadzorowane (ang. semi-supervised learning) oraz uczenie przez wzmacnianie (ang. reinforcement learning). Uczenie nadzorowane wymaga posiadania referencyjnych danych wyjściowych, ocenionych i opisanych ręcznie przez użytkownika lub przez zewnętrznych ekspertów z danej dziedziny. Sieć neuronowa przetwarza dane wejściowe, a następnie porównuje otrzymane wyniki z wynikami poprawnymi. Jedną z metod wykorzystujących tę technikę jest algorytm propagacji wstecznej (ang. backpropagation). Stosuje on gradientowe metody optymalizacji do minimalizacji różnicy błę$\mathrm{du}$ - na podstawie wyliczonego gradientu modyfikuje wagi połączeń pomiędzy neuronami. Jak wcześniej wspomniano, istnieją również sieci mogące uczyć się „,bez nauczyciela”. Próbują one przy użyciu różnych technik wykrywać wzorce wewnątrz danych, mimo braku etykiet. Metody te nie były jednak wykorzystywane w tej publikacji, więc nie są szerzej omawiane.

Pierwsze sieci neuronowe zaczęły powstawać już w latach 40. XX wieku, jednak początkowo nie dawały one zadowalających rezultatów i nie wiązano z nimi wielkich nadziei (Kurenkov, 2020). Punktem przełomowym okazały się dopiero sieci głębokie. Każda sieć neuronowa składa się z warstwy wejściowej, jednej lub więcej warstw pośrednich - nazywanych ukrytymi - i warstwy wyjściowej (Tadeusiewicz i Szaleniec, 2015). Mianem sieci głębokich określa się te architektury, które posiadają więcej niż jedną warstwę ukrytą (rys. 7). Sieci charakteryzujące się dużą ich liczbą wykazują zdolność do analizy danych na różnych poziomach abstrakcji - wczesne warstwy wykrywają szczegóły, dalsze traktują badany problem jako całość. Takie podejście pozwala rozwiązywać bardzo

Klasyczna sieć neuronowa

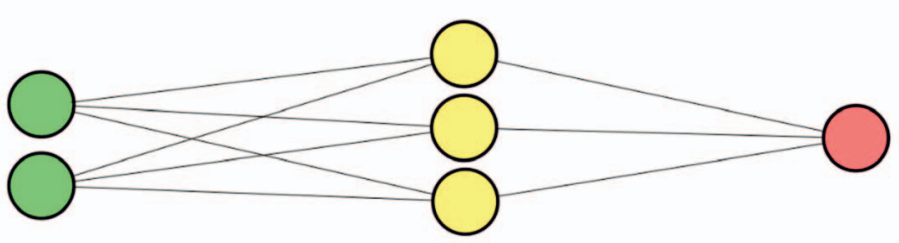

Sieć głęboka

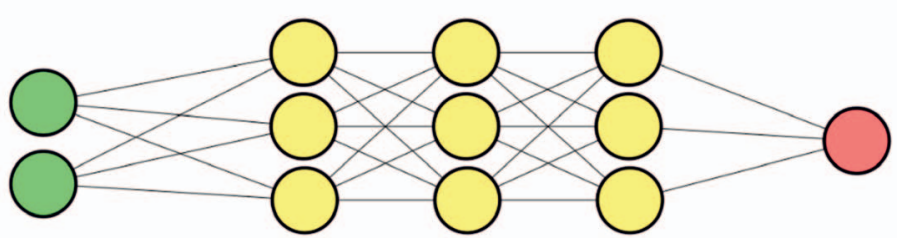

Rys. 7. Porównanie płytkiej (u góry) i głębokiej (u dołu) sieci neuronowej

Fig. 7. Comparison of shallow (top) and deep (bottom) neural networks 
skomplikowane problemy i otrzymywać wyniki o rzędy wielkości lepsze niż oferują klasyczne algorytmy uczenia maszynowego. Aby jednak móc uczyć modele sieci złożone z kilkudziesięciu, a nawet kilkuset warstw, muszą być spełnione dwa warunki: duża moc obliczeniowa i duża ilość danych treningowych. Z tego względu gwałtowny rozwój głębokich sieci neuronowych nastapił dopiero w drugiej dekadzie XXI wieku (Schmidhuber, 2015), gdy zwiększyły się możliwości nowoczesnych komputerów, a świat zaczął na dużą skalę gromadzić dane. Szczególnie istotny okazał się wpływ procesorów graficznych GPGPU (ang. general-purpose computing on graphics processing units), które pozwoliły na zrównoleglenie obliczeń.

Warto mieć świadomość, że istnieją dziesiątki rodzajów głębokich sieci neuronowych, z niezliczonymi modyfikacjami i typami architektury. O ile jeszcze na początku XXI wieku pod pojęciem „głębokie sieci” kryły się przeważnie tak zwane perceptrony wielowarstwowe (ang. multilayer perceptron) architektury złożone wyłącznie z warstw neuronów połączonych na zasadzie każdy z każdym, to dziś istnieją już techniki dużo bardziej zaawansowane. Niemniej jednak, choć najlepsze wyniki w prestiżowych konkursach osiągały w ostatnich latach architektury takie jak sieci konwolucyjne czy rekurencyjne (Russakovsky et al., 2015), to jednak podstawowe wersje perceptronów wielowarstwowych wciąż mogą znajdować szerokie zastosowanie przemysłowe.

Głębokie sieci neuronowe różnią się od siebie także ze względu na typ problemów, które rozwiązują. W dziedzinie naftowo-gazowniczej najczęściej spotkać można dwa rodzaje - problem klasyfikacji oraz problem regresji. Klasyfikację można najkrócej opisać jako przyporządkowywanie danych do dwóch lub więcej kategorii. Problem regresji polega na znalezieniu trendów i na ich podstawie uzupełnieniu brakujących elementów lub wykonaniu predykcji. Publikacja ta poświęcona jest właśnie zagadnieniu wykorzystania regresji.

Charakterystycznymi cechami sieci rozwiązujących problem regresji jest użycie liniowej funkcji aktywacji w warstwie wyjściowej oraz specyficzny dobór metryk i funkcji kosztu. Jakość otrzymanego modelu oceniana jest najczęściej za pomocą uśrednionego błędu bezwzględnego (ang. mean absolute error) lub błędu średniokwadratowego (ang. mean square error). Miary te prezentują poniższe równania:

$$
\begin{aligned}
& M A E=\frac{1}{n} \sum_{i=1}^{n}\left|y_{i}-\bar{y}\right| \\
& M S E=\frac{1}{n} \sum_{i=1}^{n}\left(y_{i}-\bar{y}\right)^{2}
\end{aligned}
$$

Wśród autorów wykorzystujących w swoich pracach naukowych w ostatnich latach działanie sieci neuronowych w charakterystyce złóż węglowodorów można wymienić takie nazwiska jak: Kholi i Arora (2014), Das i Mukerji (2019), Fajana (2020), Okon et al. (2020), Pham et al. (2020) czy Zare et al. (2020). Wśród polskich autorów warto wymienić: Darłak i Włodarczyk (2001), Jarzynę et al. (2007), Tadeusiewicza i Haducha (2015), Wawrzyniak-Guz et al. (2016), Słotę-Valim (2018), Puskarczyk (2019), Topora (2020, 2021). W geofizyce otworowej, petrofizyce i przestrzennym modelowaniu parametrycznym sztuczne sieci neuronowe mogą być wykorzystywane do predykcji parametrów na podstawie innych wielkości czy generowania tzw. metaatrybutów (pseudoparametrów), co zostało przedstawione w niniejszym artykule przy wykorzystaniu technik nadzorowanego uczenia sieci neuronowych. Do obliczeń zastosowane zostało oprogramowanie Petrel oferowane przez firmę Schlumberger.

\section{Estymacja parametryczna}

Wiarygodność modeli parametrycznych 3D charakteryzujących przestrzennie złoże, będących podstawą np. identyfikacji tzw. sweet spotów czy kalkulacji zasobów, jest tym większa, im więcej jest dostępnych wiarygodnych danych wejściowych. W zależności od ilości danych w poszczególnych otworach - informacja jest interpolowana bądź ekstrapolowana między otworami. W obliczu braku możliwości specjalistycznej interpretacji krzywych geofizyki otworowej zaprezentowana $\mathrm{w}$ artykule estymacja sieciami neuronowymi pozwala w sposób pośredni zapewnić dodatkową informację w otworze(-ach), odzwierciedlając zmienność przestrzenną analizowanego parametru. Etapem poprzedzającym modelowanie parametryczne wraz z analizą danych jest estymacja brakujących parametrów w poszczególnych profilach otworów wiertniczych uprzednio uśrednionych $\mathrm{w}$ pionowej rozdzielczości zaprojektowanej siatki interpolacyjnej (grida). W tym celu wykorzystano metodykę sieci neuronowych do odtworzenia metaatrybutów (pseudoatrybutów) parametrów o wartościach niefizycznych. Mimo to pseudoatrybuty wciąż mogą stanowić cenną informację o charakterze jakościowym. Ilościowy charakter danych zapewni natomiast procedura związana $\mathrm{z}$ analizą danych. Na tym etapie definiowane są zakresy wartości (minimalne, średnie, maksymalne) oraz krzywa dystrybucji wartości danego parametru na podstawie informacji z otworów, gdzie był on dostępny. Teoretyczne ramy procedury działania sieci neuronowych w zadaniu estymacji parametrycznej omówiono $\mathrm{w}$ poprzednim rozdziale.

Wyniki z przeprowadzonej procedury, bazującej na uśrednionych w pionowej rozdzielczości grida wartościach parametrów „uczących się” (biorące udział w procesie estymacji szacowanego parametru) i poszczególnych parametrów „uczących” (estymowany parametr dostępny w pozostałych otworach), zostały przedstawione następująco dla każdego parametru: 
1) tabela korelacyjna - współczynniki korelacji pomiędzy poszczególnymi parametrami biorącymi udział w procesie uczenia (dane wejściowe i wyjściowe) obliczone w profilach otworów wiertniczych;

2) przykłady porównania wyników w otworach, gdzie poszukiwana informacja była dostępna. Na ścieżkach przedstawione są:
a) krzywe geofizyki wiertniczej,
b) krzywe geofizyki wiertniczej uśrednione w pionowej rozdzielczości grida,
c) wyniki estymacji;

3) wykres krzyżowy ukazujący relację pomiędzy daną rzeczywistą a estymowaną (metaatrybutem analizowanego parametru) wraz ze współczynnikiem korelacji.

$\mathrm{W}$ procesie uczenia oprócz danych otworowych udział bierze informacja przestrzenna w postaci wolumenu amplitudowego. Jego uwzględnienie pozwala na przestrzenną dystrybucję poszczególnych pseudoparametrów, co z kolei daje pogląd na rozkład nie tylko w profilach analizowanych otworów, ale również w strefach pomiędzy i poza nimi, co zostało zaprezentowane w końcowym rozdziale niniejszego artykułu.

\section{Estymacja prędkości fali poprzecznej}

Fala poprzeczna S to fala sprężysta, która propagując w kierunku prostopadłym do kierunku propagacji, powoduje ruch cząsteczek ośrodka, przez który przechodzi. Prędkość fali S zależy od sprężystości i gęstości ośrodka, w którym się rozchodzi. Prędkość fali poprzecznej jest niezwykle istotną informacją pod kilkoma względami. Po pierwsze, cechą charakterystyczną fali poprzecznej S jest to, że nie propaguje w płynach. Po drugie, dynamiczne parametry sprężyste (m.in. moduł Younga, współczynnik Poissona) jako jedne $\mathrm{z}$ istotniejszych parametrów, pozwalających między innymi scharakteryzować złoże pod kątem podatności skał na zeszczelinowanie, wymagają dostępności prędkości fali poprzecznej Vs, która rzadko jest mierzona w przeciwieństwie do prędkości fali podłużnej Vp. Z kolei współczynnik VpVs, będący ilorazem prędkości fali podłużnej i prędkości fali poprzecznej, jest wskaźnikiem identyfikującym nagromadzenia węglowodorów w skale.

Poniżej zaprezentowano wyniki estymacji prędkości fali poprzecznej, która była niedostępna w dwóch (G-5 i G-6) z 10 otworów. Tabela korelacyjna (tab. 2) zestawia wartości wzajemnych relacji pomiędzy poszczególnymi parametrami biorącymi udział w procesie uczenia (AmpSEISMIC, PHI, RHOB, Vp, Vs (dostępne w pozostałych ośmiu odwiertach)) oraz wynikami estymacji pseudoparametru Vs. Analizę przeprowadzono na krzywych uśrednionych w pionowej rozdzielczości skonstruowanego wcześniej grida (ang. upscaled well logs). Najsłabszą relację zaobserwowano pomiędzy wynikiem estymacji pseudoprędkości fali poprzecznej a wolumenem amplitudowym, którego wartości uśredniono w profilach otworów. Wartość tej relacji, równą 0,31 , ocenia się jako słabą. $Z$ kolei silną relacją związane są wyniki estymacji z Vp, RHOB i PHI, z czego to właśnie z porowatością wartość korelacji jest największa. Wykres krzyżowy (rys. 8) wizualizuje z kolei relację pomiędzy danymi prędkości fali poprzecznej pomierzonymi w otworze a wynikami estymacji, wskazując korelacje pomiędzy tymi dwoma zbiorami danych na poziomie 0,8 . Na rysunku 9 zestawiono przykładowe wyniki estymacji analizowanego parametru wraz z danymi rzeczywistymi w postaci krzywych (ścieżka pierwsza) oraz w tych samych krzywych uśrednionych w pionowej rozdzielczości grida.

Tabela 2. Tabela korelacyjna prędkości fali poprzecznej oraz przestrzennych danych amplitudowych i wyników inwersji poszczególnych parametrów

Table 2. Correlation table of shear wave velocity, seismic amplitude data and inversion parameters

\begin{tabular}{|c|c|c|c|c|c|c|}
\cline { 2 - 7 } \multicolumn{1}{c|}{} & $\begin{array}{c}\text { AmpSE- } \\
\text { ISMIC }\end{array}$ & Vs & PHI & RHOB & Vp & Vs \\
\hline \hline $\begin{array}{c}\text { AmpSE- } \\
\text { ISMIC }\end{array}$ & 1,00 & 0,50 & 0,58 & 0,62 & 0,60 & 0,31 \\
\hline Vs & 0,50 & 1,00 & 0,79 & 0,78 & 0,86 & 0,58 \\
\hline PHI & 0,58 & 0,79 & 1,00 & 0,99 & 0,96 & 0,77 \\
\hline RHOB & 0,62 & 0,78 & 0,99 & 1,00 & 0,95 & 0,76 \\
\hline Vp & 0,60 & 0,86 & 0,96 & 0,95 & 1,00 & 0,74 \\
\hline Total & 0,68 & 0,88 & 0,99 & 0,99 & 0,97 & $\mathbf{0 , 8 0}$ \\
\hline
\end{tabular}

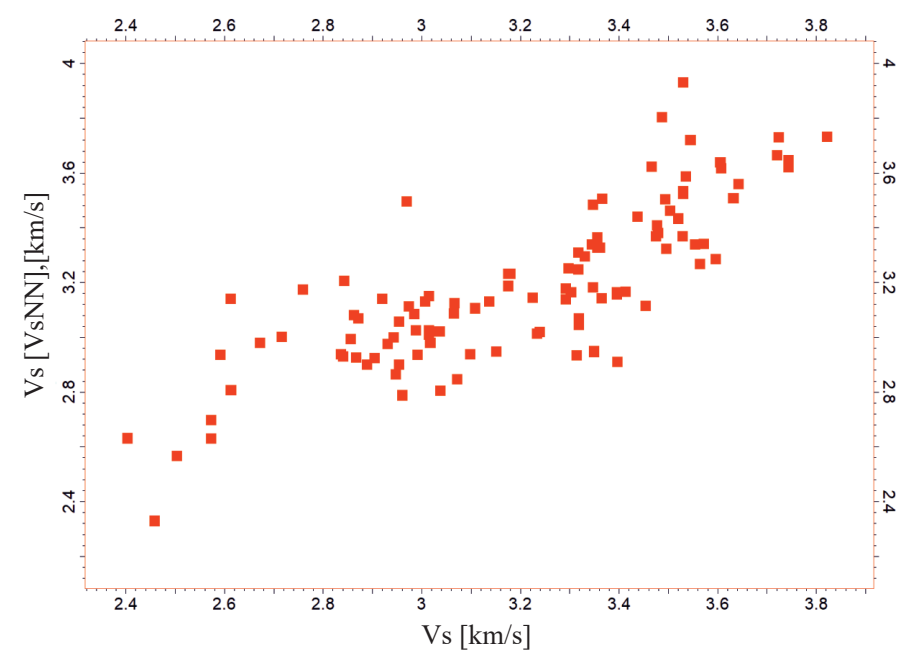

Rys. 8. Wykres zależności Vs i metaatrybutu Vs uzyskanego metodą sieci neuronowych

Fig. 8. Cross-plot of Vs and Vs meta-attribute obtained by the neural network method

\section{Estymacja porowatości efektywnej}

Porowatość jest parametrem determinującym potencjał akumulacyjny poziomu zbiornikowego i jest głównym czynnikiem warunkującym wielkość zasobów geologicznych złóż. Porowatość efektywna to z kolei parametr, który w porównaniu 


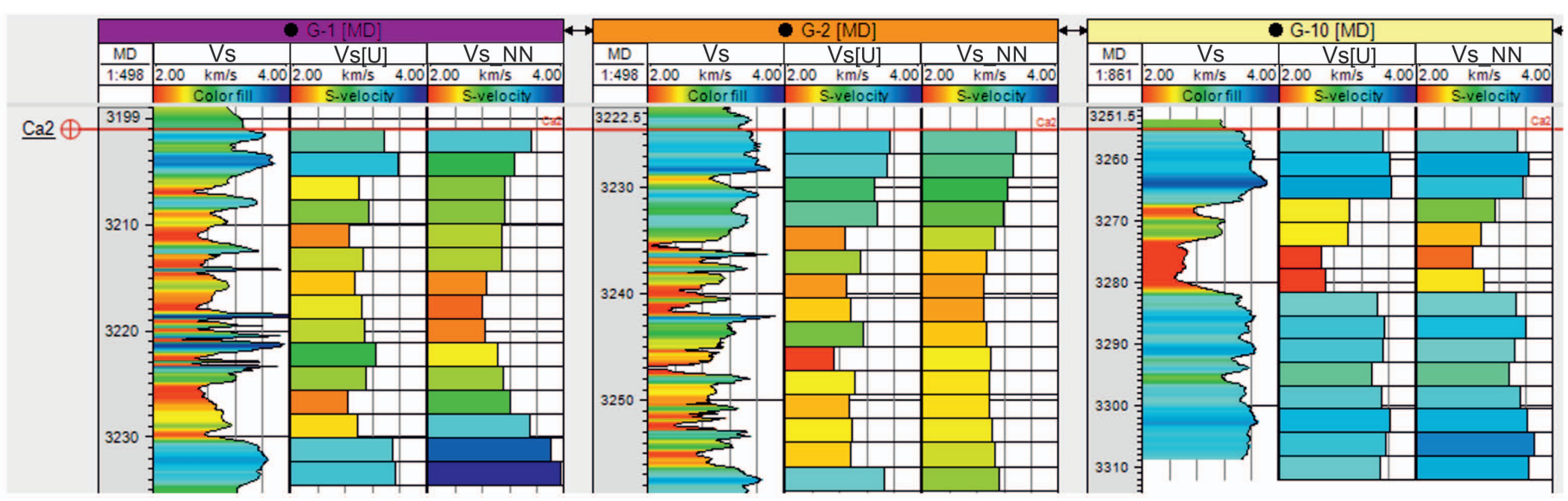

Rys. 9. Zestawienie pomierzonych i estymowanych prędkości fali poprzecznej (Vs) wzdłuż profilu otworu. Na ścieżce 1 - krzywe prędkości fali poprzecznej; ścieżka 2 - krzywa Vs uśredniona w pionowej rozdzielczości grida 3D; ścieżka 3 - Vs obliczone z wykorzystaniem sieci neuronowej

Fig. 9. Comparison of measured and estimated shear wave velocities (Vs) along the borehole profile. On the $1^{\text {st }}$ track - measured shear wave velocity $\log ; 2^{\text {nd }}$ track - upscaled Vs $\log$ in the resolution of the $3 \mathrm{D}$ grid; $3^{\text {rd }}$ track - Vs calculated with the use of a neural network

Tabela 3. Tabela korelacyjna porowatości efektywnej oraz przestrzennych danych amplitudowych i wyników inwersji poszczególnych parametrów

Table 3. Correlation table of the effective porosity actual data, seismic amplitude values and the inversion parameters values

\begin{tabular}{|c|c|c|c|c|c|c|}
\cline { 2 - 7 } \multicolumn{1}{c|}{} & $\begin{array}{c}\text { AmpSE- } \\
\text { ISMIC }\end{array}$ & Vs & PHI & RHOB & Vp & PHIE \\
\hline \hline $\begin{array}{c}\text { AmpSE- } \\
\text { ISMIC }\end{array}$ & 1,00 & 0,42 & 0,46 & 0,50 & 0,49 & 0,44 \\
\hline Vs & 0,42 & 1,00 & 0,71 & 0,70 & 0,77 & 0,52 \\
\hline PHI & 0,46 & 0,71 & 1,00 & 0,99 & 0,94 & 0,84 \\
\hline RHOB & 0,50 & 0,70 & 0,99 & 1,00 & 0,94 & 0,83 \\
\hline Vp & 0,49 & 0,77 & 0,94 & 0,94 & 1,00 & 0,77 \\
\hline Total & 0,59 & 0,78 & 0,99 & 0,99 & 0,96 & $\mathbf{0 , 8 6}$ \\
\hline
\end{tabular}

z porowatością całkowitą jest istotniejszy z punktu widzenia złożowego z uwagi na mobilność mediów złożowych. Analogicznie jak we wcześniejszym przykładzie porowatość efektywna została wyestymowana w profilach otworów, gdzie ta informacja nie była dostępna (tj. G-4K, G-10, G-12). Relacje pomiędzy wynikiem estymacji a parametrami biorącymi udział w procesie uczenia (tab. 3) są silniejsze w porównaniu z wcześniejszym przykładem. Podobnie najsłabszą korelacją charakteryzował się związek pomiędzy wynikiem estymacji a wolumenem amplitudowym (wartość równa 0,46) a najsilniejszą - w relacji z porowatością całkowitą (bardzo silna relacja na poziomie niemalże 0,85$)$. Analizując relację pomiędzy wynikiem estymacji pseudoporowatości efektywnej i porowatości efektywnej, będącej wynikiem interpretacji krzywych geofizyki wiertniczej (rys. 11), kalibrowanej wynikami badań laboratoryjnych, widać dużą zbieżność wyników estymowanych z rzeczywistymi, co potwierdza wykres krzyżowy oraz wartość współczynnika korelacji $(0,89)$ przedstawione na rysunku 10 .

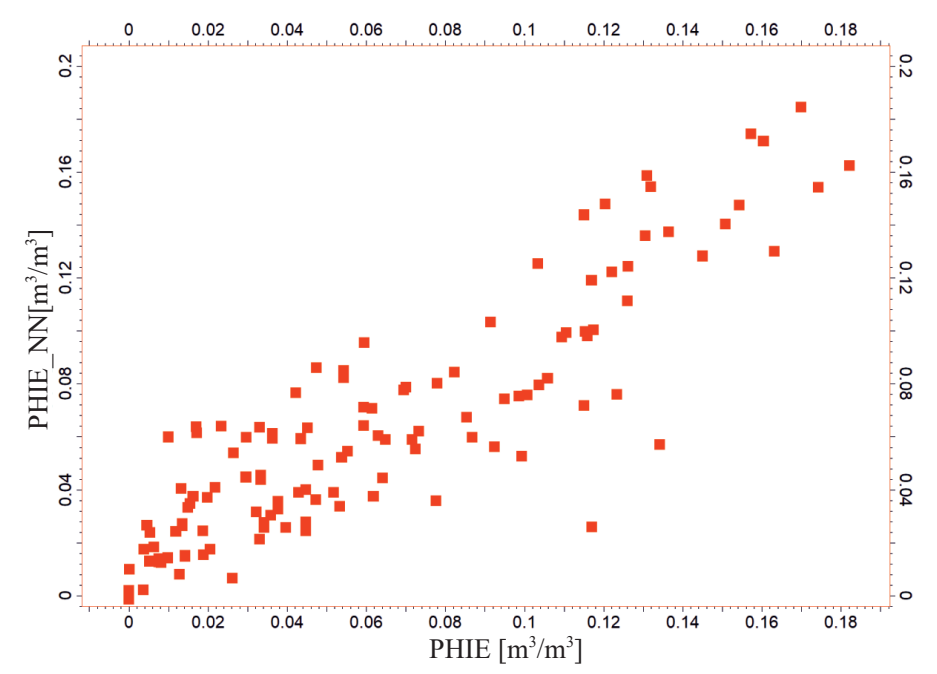

Rys. 10. Wykres zależności PHIE i metaatrybutu PHIE uzyskanego metodą sieci neuronowych

Fig. 10. Effective porosity and effective porosity meta-attribute cross-plot

\section{Estymacja nasycenia weglowodorami}

Nasycenie węglowodorami jest parametrem mówiącym o objętości wolnej przestrzeni porowej, która nie jest zajęta przez wodę (1-Sw) i tym samym obejmuje zawartość węglowodorów. Dane dotyczące tego parametru nie były dostępne w dwóch otworach: G-4K, G-12. Relacje pomiędzy wynikiem estymacji parametru nasycenia węglowodorami a parametrami biorącymi w procesie uczenia są słabe (wartość korelacji we wszystkich przypadkach wynosi poniżej 0,2) (tab. 4). Niemniej jednak, porównując dane rzeczywiste z wynikami estymacji zaaplikowanej procedury sieci neuronowych i wyznaczając zależność pomiędzy tymi dwoma zbiorami danych pochodzącymi z ośmiu otworów, otrzymujemy wartość współczynnika korelacji na poziomie 0,58 (rys. 12). Porównanie danych rzeczywistych i estymowanych zaprezentowano na kilku 


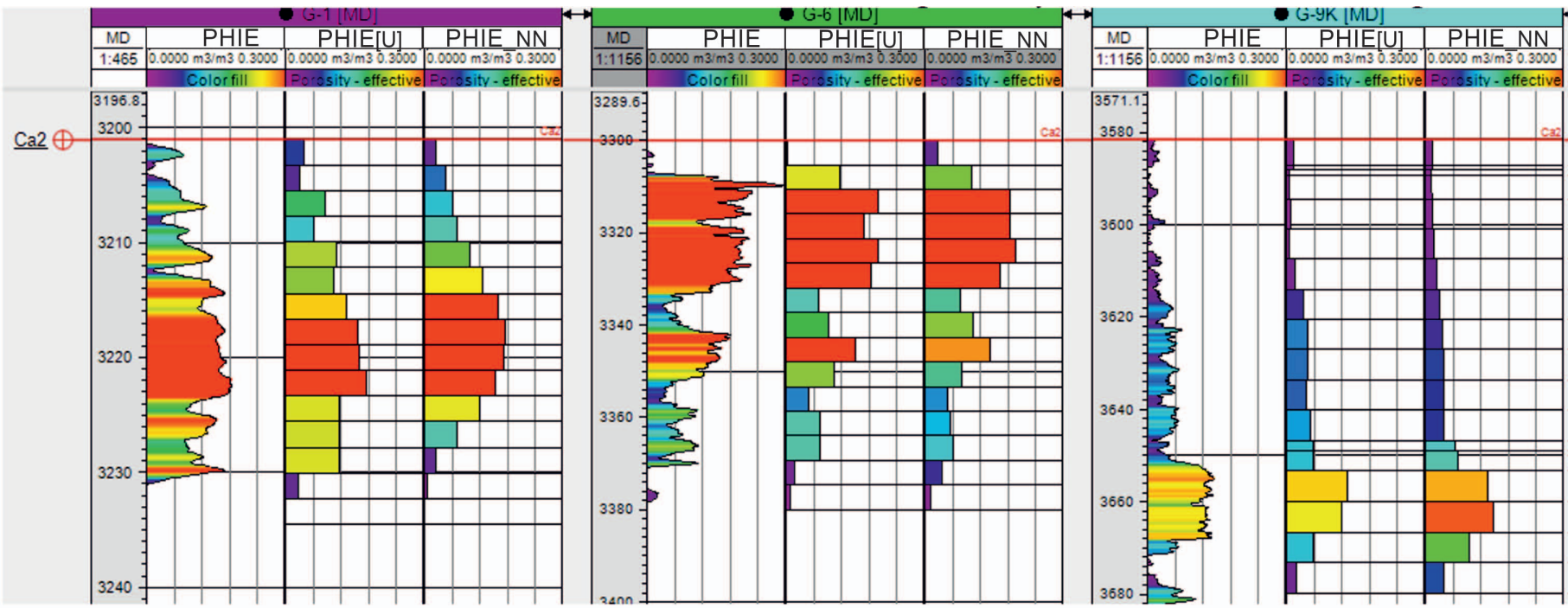

Rys. 11. Zestawienie pomierzonych i estymowanych porowatości efektywnych (PHIE) wzdłuż profilu otworu. Na ścieżce 1 - krzywe porowatości efektywnej; ścieżka 2 - krzywa PHIE uśredniona w pionowej rozdzielczości grida 3D; ścieżka 3 - PHIE obliczone z wykorzystaniem sieci neuronowej

Fig. 11. Comparison of measured and estimated effective porosity (PHIE) along the borehole profile. On the $1^{\text {st }}$ track - measured effective porosity log; $2^{\text {nd }}$ track - upscaled PHIE log in the resolution of the $3 \mathrm{D}$ grid; $3^{\text {rd }}$ track - PHIE calculated with the use of a neural network

Tabela 4. Tabela korelacyjna nasycenia węglowodorami oraz przestrzennych danych amplitudowych i wyników inwersji poszczególnych parametrów

Table 4. Correlation table of the hydrocarbon saturation actual data, seismic amplitude values and the inversion parameters values

\begin{tabular}{|c|c|c|c|c|c|c|}
\cline { 2 - 7 } & $\begin{array}{c}\text { AmpSE- } \\
\text { ISMIC }\end{array}$ & Vs & PHI & RHOB & Vp & $\mathbf{1 - S w}$ \\
\hline \hline $\begin{array}{c}\text { AmpSE- } \\
\text { ISMIC }\end{array}$ & 1,00 & 0,48 & 0,53 & 0,57 & 0,54 & 0,13 \\
\hline Vs & 0,48 & 1,00 & 0,76 & 0,76 & 0,80 & 0,16 \\
\hline PHI & 0,53 & 0,76 & 1,00 & 0,99 & 0,95 & 0,16 \\
\hline RHOB & 0,57 & 0,76 & 0,99 & 1,00 & 0,95 & 0,15 \\
\hline Vp & 0,54 & 0,80 & 0,95 & 0,95 & 1,00 & 0,19 \\
\hline Total & 0,65 & 0,80 & 0,99 & 0,99 & 0,96 & $\mathbf{0 , 2 3}$ \\
\hline
\end{tabular}

przykładach na rysunku 13. Wykorzystanie poniższych wyników w kolejnych krokach, np. modelowania przestrzennego, wymagałoby wykroczenia poza zaprezentowany zakres metodyczny i wykonania bardziej szczegółowych analiz, o ile niemożliwe byłoby przeprowadzenie standardowej interpretacji geofizycznej, na podstawie której możliwa byłaby najprecyzyjniejsza identyfikacja nasycenia mediami złożowymi.

\section{Estymacja modulu Younga}

Moduł Younga jest parametrem definiującym sprężystość materiału przy rozciąganiu i ściskaniu. W kontekście oceny złożowej jest to parametr niezwykle istotny przy charakterystyce podatności skał na zniszczenia mechaniczne (prowadzące do powstania szczelin, czyli ścieżek migracji płynów złożowych), który to parametr często podlega analizie przy

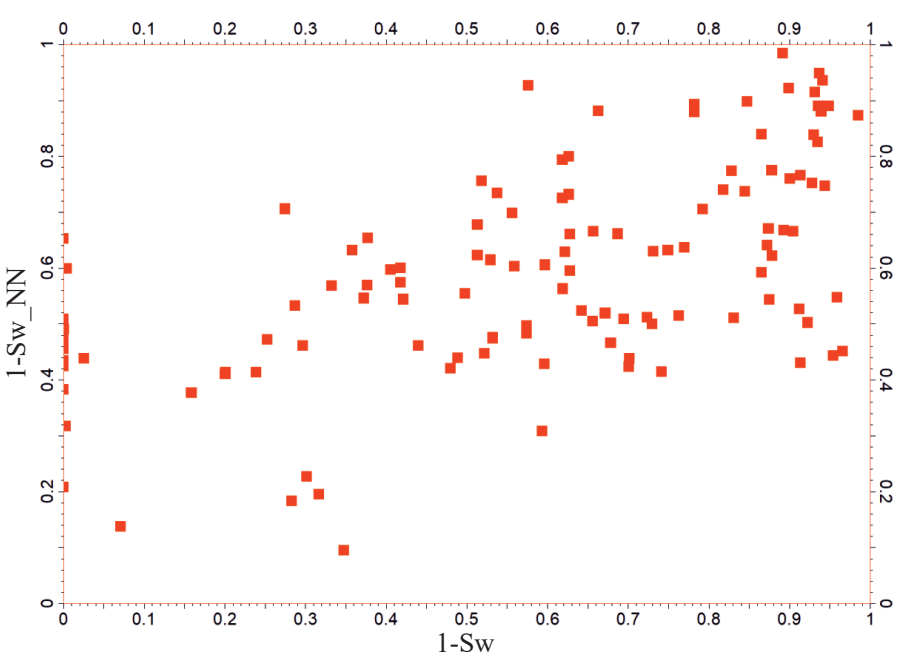

Rys. 12. Wykres zależności 1-Sw i metaatrybutu 1-Sw uzyskanego metodą sieci neuronowych

Fig. 12. Cross plot of the hydrocarbon saturation meta-attribute and the hydrocarbon saturation actual data

ocenie efektywności skał na zabiegi szczelinowania. Pomiary modułu Younga nie były dostępne, podobnie jak prędkość fali poprzecznej, w trzech otworach: G-5 i G-6 oraz G-8K. Dysponując wyestymowanym parametrem Vs w tych otworach, dynamiczne wartości modułu Younga można obliczyć, wykorzystując następującą formułę (gdzie $V p$ - prędkość fali podłużnej, $V_{S}$ - prędkość fali poprzecznej):

$$
E_{d y n}=\rho V s^{2}\left(\frac{3 V p^{2}-4 V s^{2}}{V p^{2}-V s^{2}}\right)
$$

Pomimo możliwości kalkulacji wartości tego parametru według powyższego wzoru - w ramach niniejszego artykułu 


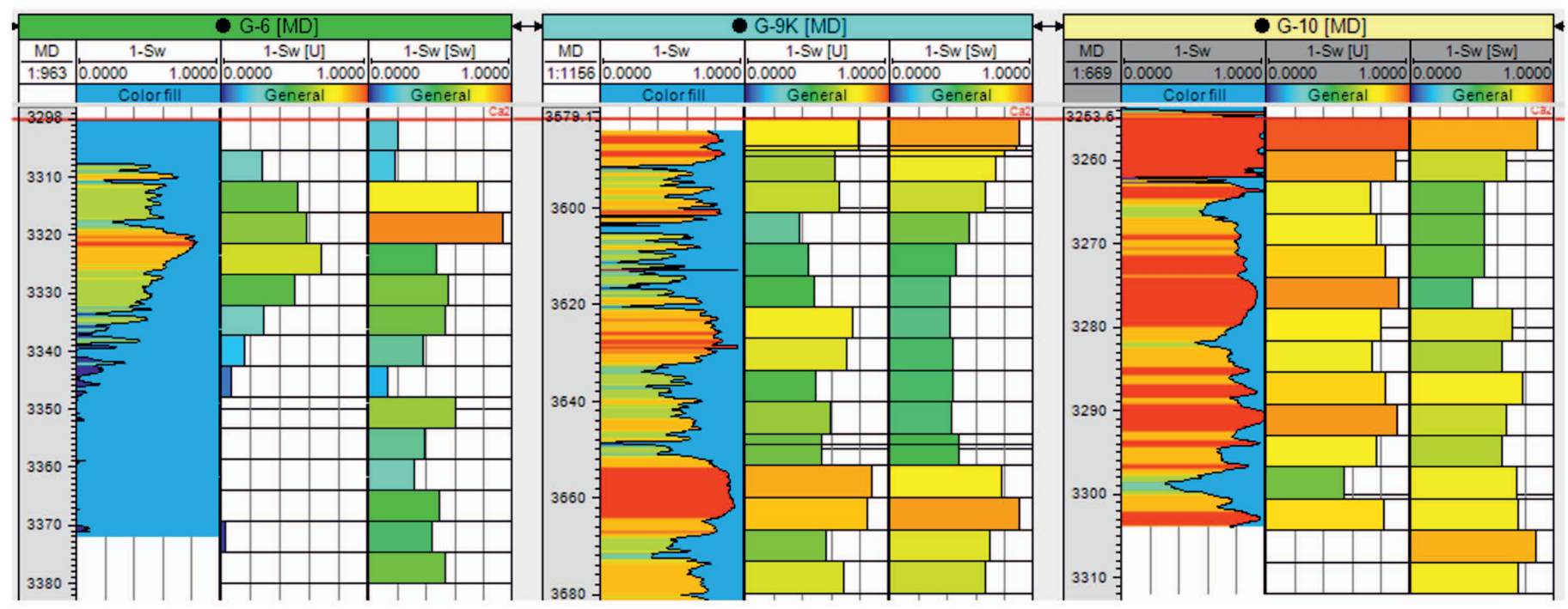

Rys. 13. Zestawienie pomierzonych i estymowanych nasyceń węglowodorami (1-Sw) wzdłuż profilu otworu. Na ścieżce 1 - interpretacje nasycenia węglowodorami; ścieżka 2 - krzywa 1-Sw uśredniona w pionowej rozdzielczości grida 3D; ścieżka 3 - 1-Sw obliczone z wykorzystaniem sieci neuronowej

Fig. 13. Comparison of measured and estimated hydrocarbon saturation (1-Sw) along the borehole profile. On the $1^{\text {st }}$ track - interpretation $\log$ of hydrocarbon saturation; $2^{\text {nd }}$ track - upscaled $1-\mathrm{Sw} \log$ in the resolution of the $3 \mathrm{D}$ grid; $3^{\text {rd }}$ track -1 -Sw calculated with the use of a neural network

Tabela 5. Tabela korelacyjna modułu Younga oraz przestrzennych danych amplitudowych i wyników inwersji poszczególnych parametrów

Table 5. Correlation table of the Young modulus actual data, seismic amplitude values and the inversion parameters values

\begin{tabular}{|c|c|c|c|c|c|c|}
\cline { 2 - 7 } \multicolumn{1}{c|}{} & $\begin{array}{c}\text { AmpSE- } \\
\text { ISMIC }\end{array}$ & Vs & PHI & RHOB & Vp & YD \\
\hline \hline $\begin{array}{c}\text { AmpSE- } \\
\text { ISMIC }\end{array}$ & 1,00 & 0,40 & 0,46 & 0,50 & 0,46 & 0,31 \\
\hline Vs & 0,40 & 1,00 & 0,68 & 0,67 & 0,80 & 0,60 \\
\hline PHI & 0,46 & 0,68 & 1,00 & 0,99 & 0,94 & 0,82 \\
\hline RHOB & 0,50 & 0,67 & 0,99 & 1,00 & 0,92 & 0,83 \\
\hline Vp & 0,46 & 0,80 & 0,94 & 0,92 & 1,00 & 0,83 \\
\hline Total & 0,55 & 0,82 & 0,99 & 0,99 & 0,96 & $\mathbf{0 , 8 5}$ \\
\hline
\end{tabular}

kontynuowano estymację poprowadzoną poprzez zastosowanie sieci neuronowych. Spośród wszystkich estymowanych parametrów to właśnie moduł Younga wykazuje najwyższe współczynniki korelacji z parametrami biorącymi udział w procesie uczenia sieci neuronowych (średnia równa 0,85 ). W przypadku trzech parametrów (PHI, RHOB, Vp) relacja ta jest bardzo zbliżona $(\sim 0,85)$. Podobnie jak w poprzednich przypadkach najsłabiej z wynikami koreluje wolumen amplitudowy (wartość korelacji równa 0,31 ). $Z$ drugiej strony - relacja pomiędzy wynikiem estymacji w formie pseudomodułu Younga (parametr o niefizycznym charakterze) a wynikami rzeczywistymi z pozostałych ośmiu otworów jest bardzo silna, przy współczynniku korelacji 0,86 (rys. 14). Wyniki w formie graficznej przedstawiono w tabeli 5. Zestawienie pomierzonych i estymowanych wartości tego parametru w wybranych otworach przedstawiono na rysunku 15 .

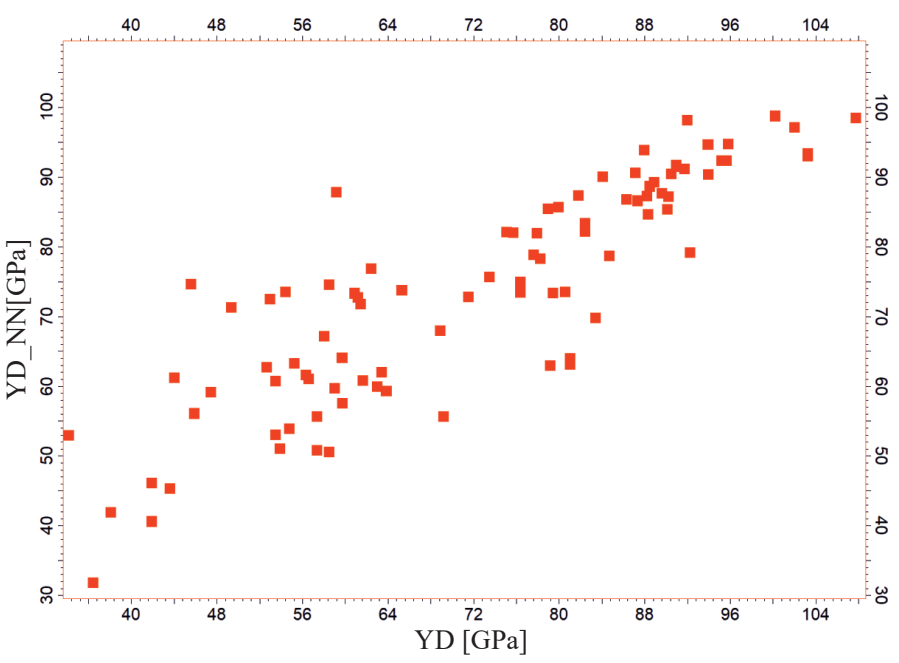

Rys. 14. Wykres zależności modułu Younga i metaatrybutu modułu Younga uzyskanego metodą sieci neuronowych

Fig. 14. Cross plot of the Young modulus acutal data and the Young modulus meta-attribute

\section{Estymacja wspótczynnika Poissona}

Ostatni z estymowanych parametrów dotyczy współczynnika Poissona. Podobnie jak w przypadku modułu Younga parametr ten w formie dynamicznej, zważywszy na fakt dostępności prędkości fali poprzecznej w każdym z otworów (w wyniku estymacji będącej przedmiotem niniejszego artykułu), może zostać obliczony według następującego wzoru:

$$
v_{d y n}=V p^{2}-\frac{V s^{2}}{2\left(V p^{2}-V s^{2}\right)}
$$

Na potrzeby realizacji zadania będącego celem publikacji, wykorzystując metodologię sieci neuronowych, estymacji poddano 


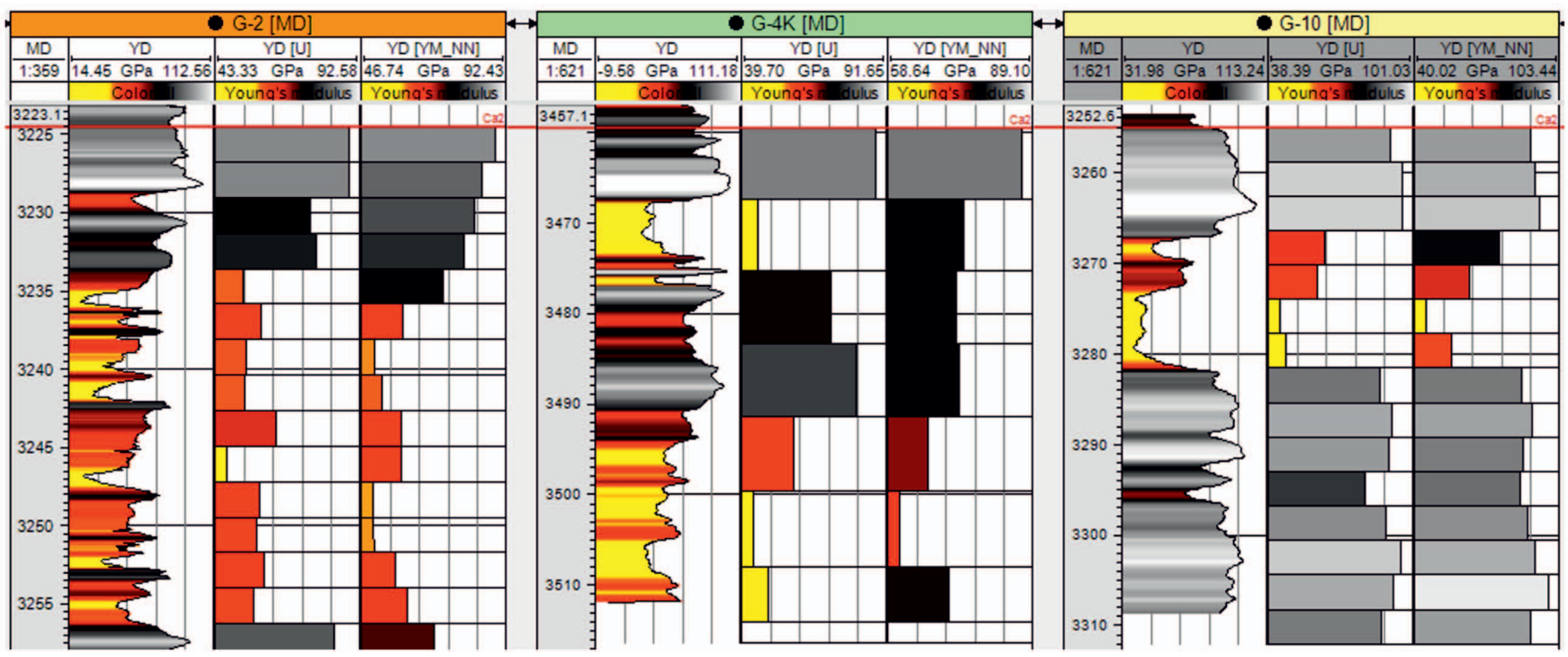

Rys. 15. Zestawienie pomierzonych i estymowanych wartości modułu Younga (YD) wzdłuż profilu otworu. Na ścieżce 1 - krzywe modułu Younga; ścieżka 2 - krzywa YD uśredniona w pionowej rozdzielczości grida 3D; ścieżka 3 - YD obliczone z wykorzystaniem sieci neuronowej

Fig. 15. Comparison of measured and estimated Young modulus (YD) along the borehole profile. On the $1^{\text {st }}$ track - measured Young modulus $\log ; 2^{\text {nd }}$ track - upscaled YD log in the resolution of the $3 \mathrm{D}$ grid; $3^{\text {rd }}$ track - YD calculated with the use of a neural network

Tabela 6. Tabela korelacyjna współczynnika Poissona oraz przestrzennych danych amplitudowych i wyników inwersji poszczególnych parametrów

Table 6. Correlation table of the Poisson ratio actual data, seismic amplitude values and the inversion parameters values

\begin{tabular}{|c|c|c|c|c|c|c|}
\cline { 2 - 7 } \multicolumn{1}{c|}{} & $\begin{array}{c}\text { AmpSE- } \\
\text { ISMIC }\end{array}$ & Vs & PHI & RHOB & Vp & POIS \\
\hline \hline $\begin{array}{c}\text { AmpSE- } \\
\text { ISMIC }\end{array}$ & 1,00 & 0,40 & 0,46 & 0,50 & 0,46 & 0,29 \\
\hline Vs & 0,40 & 1,00 & 0,68 & 0,67 & 0,80 & 0,39 \\
\hline PHI & 0,46 & 0,68 & 1,00 & 0,99 & 0,94 & 0,70 \\
\hline RHOB & 0,50 & 0,67 & 0,99 & 1,00 & 0,92 & 0,67 \\
\hline Vp & 0,46 & 0,80 & 0,94 & 0,92 & 1,00 & 0,64 \\
\hline Total & 0,55 & 0,82 & 0,99 & 0,99 & 0,96 & $\mathbf{0 , 7 3}$ \\
\hline
\end{tabular}

współczynnik Poissona. Niskie wartości tego sprężystego parametru identyfikują nasycenie węglowodorami. Współczynnik Poissona również często wykorzystywany jest wraz z modułem Younga jako wskaźnik kruchości (ang. brittleness index).

W wyniku zaaplikowania procedury sieci neuronowych (tab. 6), w których udział w procesie uczenia bierze ten sam zestaw parametrów co w poprzednich przypadkach, wyestymowano pseudowspółczynnik Poissona w trzech otworach (G-5, G-6, G-8K). Słaby współczynnik korelacji zanotowano w przypadku relacji pomiędzy wynikiem a wolumenem amplitudowym $(0,28)$ i prędkością fali poprzecznej $(0,39)$, w pozostałych przypadkach relacje są dobre (pomiędzy 0,63 a 0,7 wartości współczynnika korelacji). Pseudoparametr w zestawieniu ze współczynnikiem Poissona dostępnym w otworach

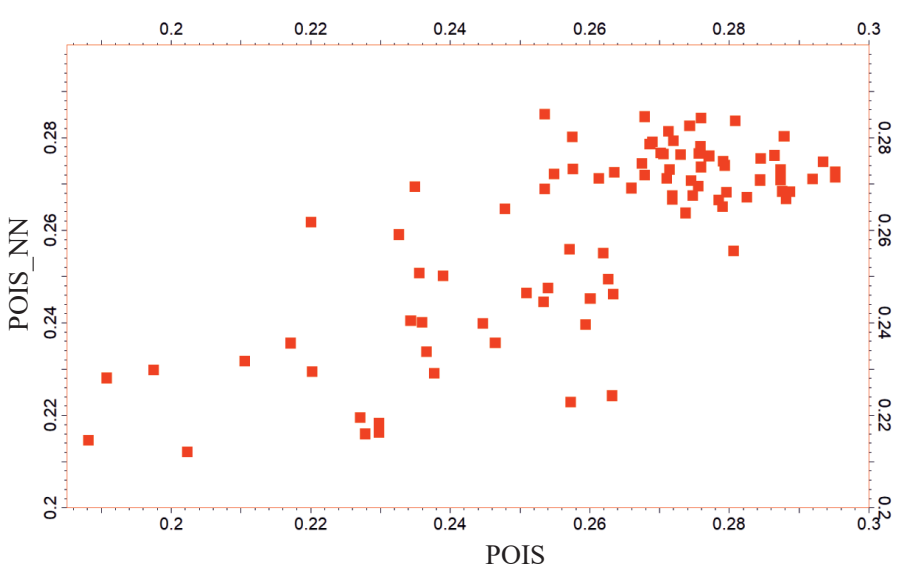

Rys. 16. Wykres zależności współczynnika Poissona i metaatrybutu współczynnika Poissona uzyskanego metodą sieci neuronowych

Fig. 16. Cross plot of the Poisson ratio acutal data and the Poisson ratio meta-attribute

wiertniczych charakteryzuje się współczynnikiem korelacji na poziomie 0,75 (rys. 16). Pomiar rzeczywisty, jego uśrednienie w pionowej rozdzielczości skonstruowanego grida oraz wyniki estymacji analizowanego parametru przedstawia rysunek 17 .

\section{Walidacja uzyskanych wyników}

W celu jakościowej oceny uzyskanych wyników przeprowadzono walidację rezultatów estymacji poszczególnych parametrów (Vs, PHIE, 1-Sw, YM, PR) w odniesieniu do rzeczywistych pomiarów tych parametrów w otworach, gdzie te informacje były dostępne. Istota prezentowanej procedury walidacyjnej polega na porównaniu danych rzeczywistych 


\section{NAFTA-GAZ}
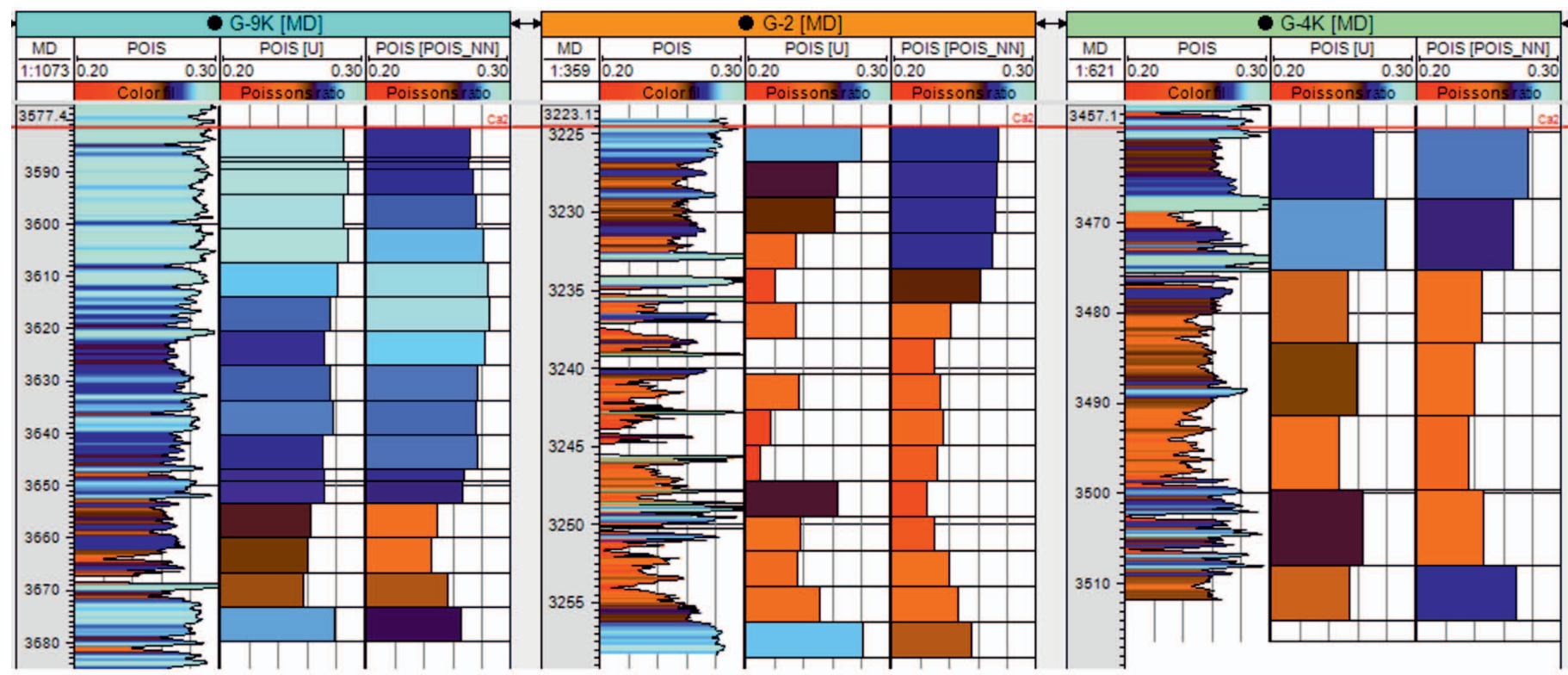

Rys. 17. Zestawienie pomierzonych i estymowanych wartości współczynnika Poissona (POIS) wzdłuż profilu otworu. Na ścieżce 1 krzywe współczynnika Poissona; ścieżka 2 - krzywa POIS uśredniona w pionowej rozdzielczości grida 3D; ścieżka 3 - POIS obliczone z wykorzystaniem sieci neuronowej

Fig. 17. Comparison of measured and estimated Poisson ratio (POIS) along the borehole profile. On the $1^{\text {st }}$ track - measured Poisson ratio $\log ; 2^{\text {nd }}$ track - upscaled POIS log in the resolution of the $3 \mathrm{D}$ grid; $3^{\text {rd }}$ track - POIS calculated with the use of a neural network

z wynikami zastosowanej metody (w przypadku niniejszego artykułu było to użycie sieci neuronowych) celem wzajemnej konfrontacji i weryfikacji metod geostatystycznych (Sowiżdżał, 2013). Obliczono różnicę pomiędzy profilem rzeczywistym i estymowanym (parametr R), jak również pierwiastek błędu średniokwadratowego (ang. root-mean-square error, RMSE). Różnice (R) wskazują na niedoszacowane (wartości ujemne) oraz przeszacowane (wartości dodatnie) wartości analizowanego parametru. Dodatkowo obliczono także znormalizowany błąd średniokwadratowy wyrażony w procentach (NormRMSE).

Do tego celu wykorzystano poniższe formuły:

$$
R=\text { wartość zmierzona - wartość estymowana }
$$

\section{$R M S E=\sqrt[2]{(\text { wartość zmierzona }- \text { wartość estymowana })^{2}}$}

$$
\text { NormRMSE }=\left(\begin{array}{c}
\frac{\text { RMSE }}{\text { wartość zmirzona }_{\text {max }}-} \\
- \text { wartość zmierzona }_{\text {min }}
\end{array}\right) \cdot 100
$$

Tabela 7. Wartości parametrów R, RMSE i RMSE znormalizowane dla poszczególnych parametrów w kolejnych otworach

\begin{tabular}{|c|c|c|c|c|c|c|c|c|c|c|c|}
\hline & & G-1 & G-2 & G-5 & G-6 & G-8H & G-9K & G-4K & G-8K & G-10 & G-12 \\
\hline \multirow{3}{*}{ Vs } & $\mathrm{R}$ & $-0,07$ & 0,05 & - & - & 0,09 & 0,08 & $-0,04$ & 0,07 & $-0,05$ & $-0,08$ \\
\hline & RMSE & 0,21 & 0,13 & - & - & 0,18 & 0,10 & 0,32 & 0,10 & 0,09 & 0,12 \\
\hline & NormRMSE & 29,35 & 16,63 & - & - & 36,11 & 10,82 & 36,28 & 13,73 & 8,67 & 12,48 \\
\hline \multirow{3}{*}{ PHIE } & R & 0,01 & 0,00 & 0,00 & 0,00 & $-0,01$ & $-0,01$ & - & 0,00 & - & - \\
\hline & RMSE & 0,02 & 0,02 & 0,01 & 0,01 & 0,02 & 0,01 & - & 0,02 & - & - \\
\hline & NormRMSE & 12,91 & 12,46 & 11,49 & 5,66 & 27,28 & 7,97 & - & 17,14 & - & - \\
\hline \multirow{3}{*}{ 1-Sw } & $\overline{\mathrm{R}}$ & 0,07 & 0,20 & $-0,04$ & $-0,23$ & $-0,23$ & 0,01 & - & $-0,04$ & 0,16 & $\begin{array}{l}- \\
\end{array}$ \\
\hline & RMSE & 0,17 & 0,20 & 0,20 & 0,28 & 0,30 & 0,11 & - & 0,13 & 0,19 & - \\
\hline & NormRMSE & 62,18 & 215,49 & 31,68 & 40,95 & 56,41 & 21,88 & - & 21,63 & 42,76 & - \\
\hline \multirow{3}{*}{ YD } & $\overline{\mathrm{R}}$ & $-2,64$ & $-0,13$ & - & - & $-0,08$ & 1,66 & "-10,09 & - & $-2,38$ & $-5,34$ \\
\hline & RMSE & 7,80 & 5,74 & - & - & 8,92 & 4,36 & 12,33 & - & 3,86 & 7,04 \\
\hline & NormRMSE & 19,72 & 13,99 & - & - & 34,07 & 8,04 & 28,49 & - & 7,39 & 15,72 \\
\hline \multirow{3}{*}{ POIS } & $\mathrm{R}$ & 0,00 & $-0,01$ & - & - & 0,02 & 0,01 & 0,01 & - & $-0,01$ & 0,00 \\
\hline & RMSE & 0,01 & 0,02 & - & - & 0,02 & 0,01 & 0,01 & - & 0,01 & 0,01 \\
\hline & NormRMSE & 13,79 & 21,03 & - & - & 30,84 & 28,25 & 40,45 & - & 23,51 & 41,23 \\
\hline
\end{tabular}

Table 7. R, RMSE, RMSE normalized parameters values for analyzed parameters in each borehole 


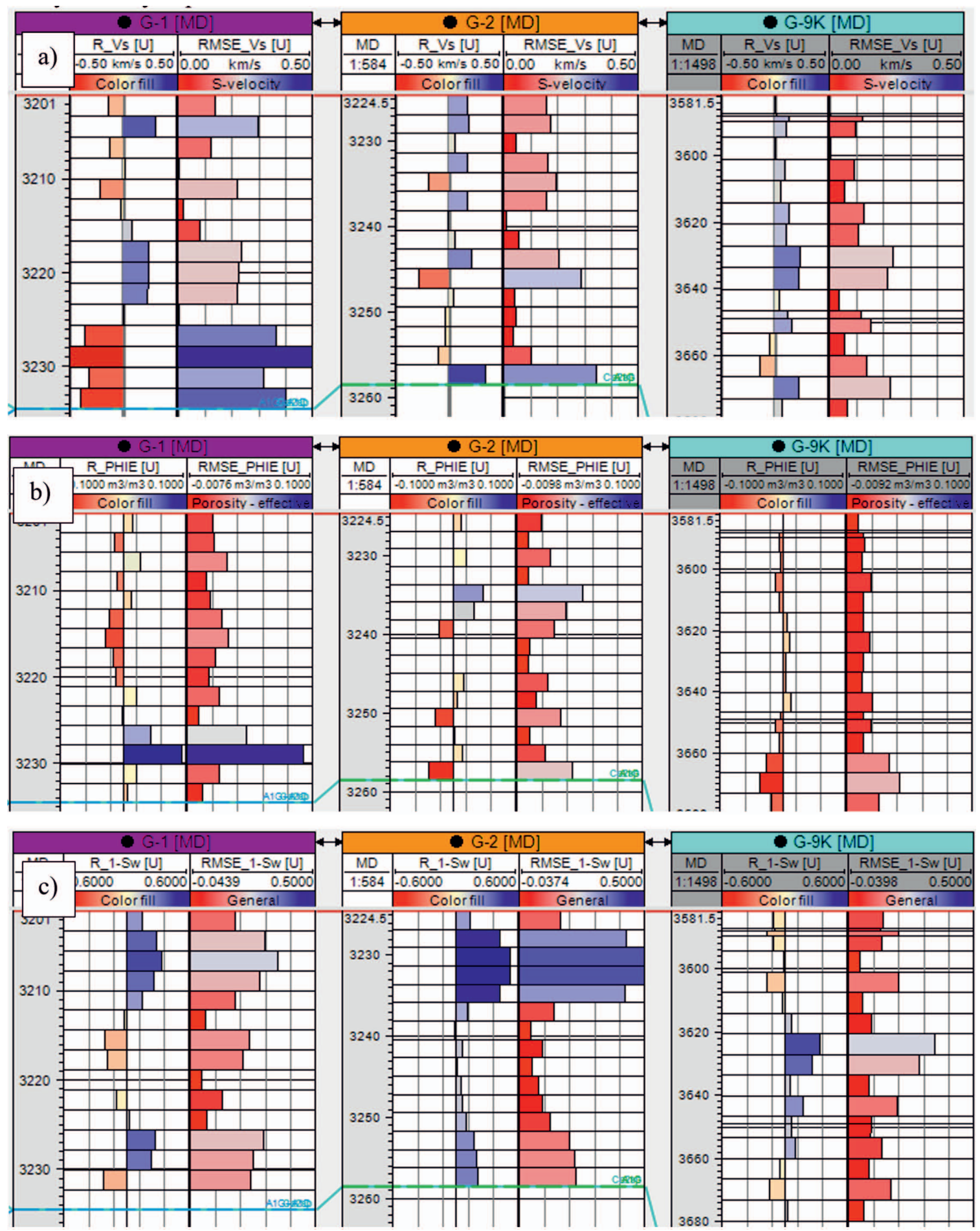

Rys. 18. Walidacja wyników estymacji: a) prędkości fali poprzecznej, b) porowatości efektywnej, c) nasycenia węglowodorami - w wybranych trzech otworach

Fig. 18. Validation of estimated results of a) shear wave velocity, b) effective porosity, c) hydrocarbon saturation for selected boreholes

W ramach przedstawienia przykładów zaprezentowano wyniki analizy walidacyjnej w otworach, gdzie dostępny był pełen zestaw danych (tj. G-1, G-2, G-9K). Analizę poprowadzono w profilach uśrednionych do pionowej rozdzielczości grida. Wyniki zastosowania powyżej opisanych formuł zaaplikowanych dla każdego z estymowanych parametrów w poszczególnych otworach przedstawiono w tabeli 7 oraz na rysunku 18 i 19. W tabeli pogrubioną czcionką uwydatniono maksymalne (czarne) i minimalne (czerwone) wartości parametru NormRMSE, dla których im mniejsza ich różnica, tym większa wiarygodność uzyskanych wyników estymacji.

Wartości parametru R na pierwszej ścieżce są podzielone na dwie grupy: ujemne oraz dodatnie. Wzrost intensywności koloru czerwonego oznacza coraz to większe niedoszacowanie wartości analizowanego parametru, natomiast intensywniejsza barwa niebieska wskazuje na przeszacowanie wartości. 

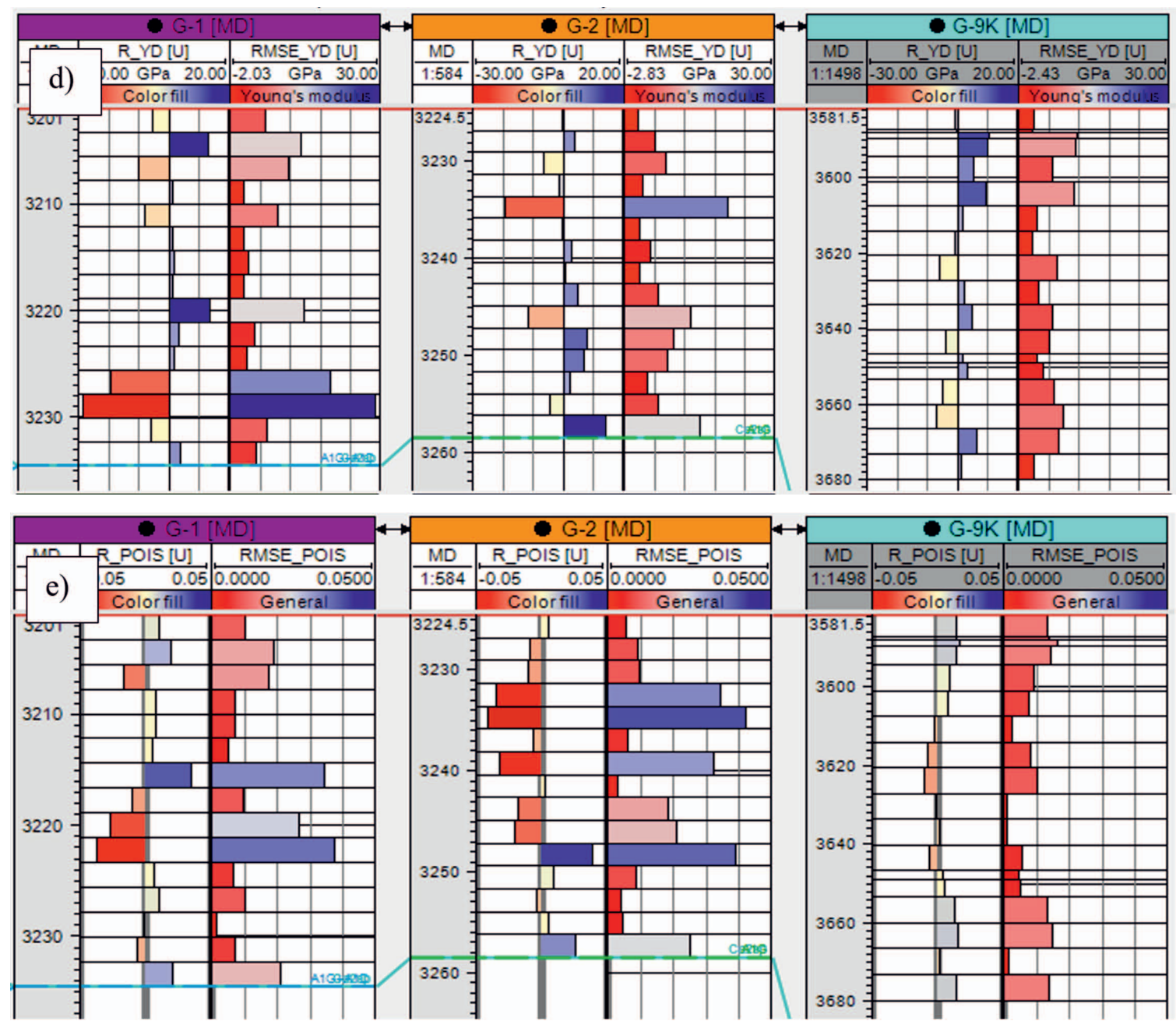

Rys. 19. Walidacja wyników estymacji: d) modułu Younga, e) współczynnika Poissona - w wybranych trzech otworach

Fig. 19. Validation pf estimated results of: d) Young modulus, e) Poisson ratio in selected boreholes

Na drugiej ścieżce widnieje wykres błędu średniokwadratowego jako ogólnej miary błędu predykcji. Spośród wszystkich analizowanych parametrów w otworach najmniejszym błędem predykcji charakteryzowały się wyniki estymacji w odwiercie G-9K, na co wskazują słabe intensywności koloru na ścieżce 1 oraz niskie wartości RMSE dla każdego z estymowanych parametrów.

\section{Przestrzenna charakterystyka uzyskanych wyników}

Zastosowanie opisanych wcześniej procedur i estymacja poszczególnych parametrów w kolejnych otworach pozwoliły w następnym kroku przeprowadzić modelowanie przestrzenne z pełnym zakresem danych w profilach analizowanych otworów wiertniczych. Zestaw danych został uzupełniony o 18 estymowanych danych (tab. 1), których dostępność, w teorii, zwiększa wiarygodność uzyskanych wyników modelowania. Procedura modelowania przestrzennego została poprzedzona transformacją danych, w celu nadania poszczególnym parametrom charakteru fizycznego, polegającą za zaaplikowaniu odpowiednich, wynikających z analizy pozostałych danych, zakresów wartości oraz charakteru krzywej dystrybucji. Tak przygotowane dane stanowią podstawę do dalszych analiz złożowych. W ramach przedstawienia przykładu zaaplikowania powyżej opisanych wyników skonstruowano przestrzenne modele parametryczne zaprezentowane na rysunkach poniżej (rys. 20-24). Celem przedstawienia różnic pomiędzy analizą przestrzenną ograniczonego zestawu dostępnych danych a zestawu danych uzupełnionych estymowanymi parametrami zaprezentowano mapy średnich wartości dwóch modeli porowatości efektywnej opartych na odmiennym zestawie danych (rys. 25).

\section{Podsumowanie}

Problematyka poruszona w artykule dotyczy możliwości wykorzystania sztucznych sieci neuronowych w predykcji parametrycznej celem uzupełnienia bazy danych 


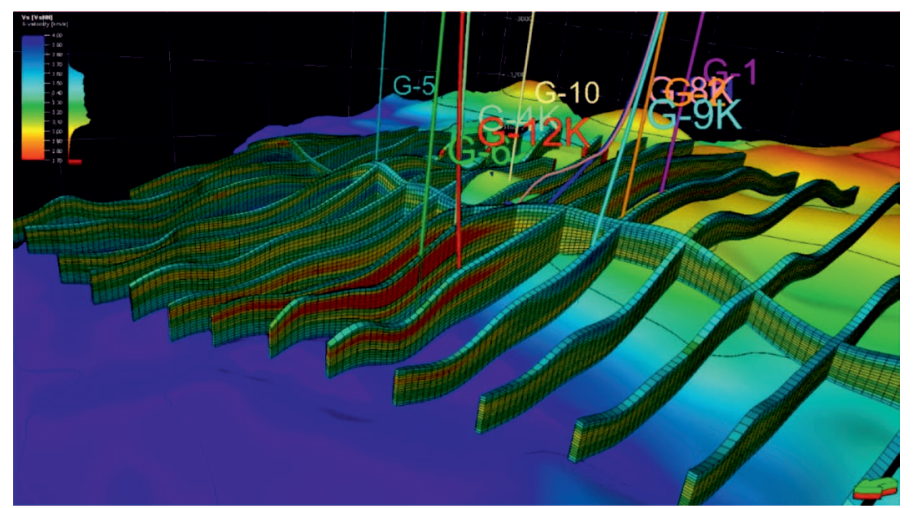

Rys. 20. Model prędkości fali poprzecznej w obrębie analizowanego obszaru uwzględniający estymowane dane w otworach G-5 i G-6

Fig. 20. Shear wave velocity model within analyzed area considering estimated values in borehole G-5 and G-6

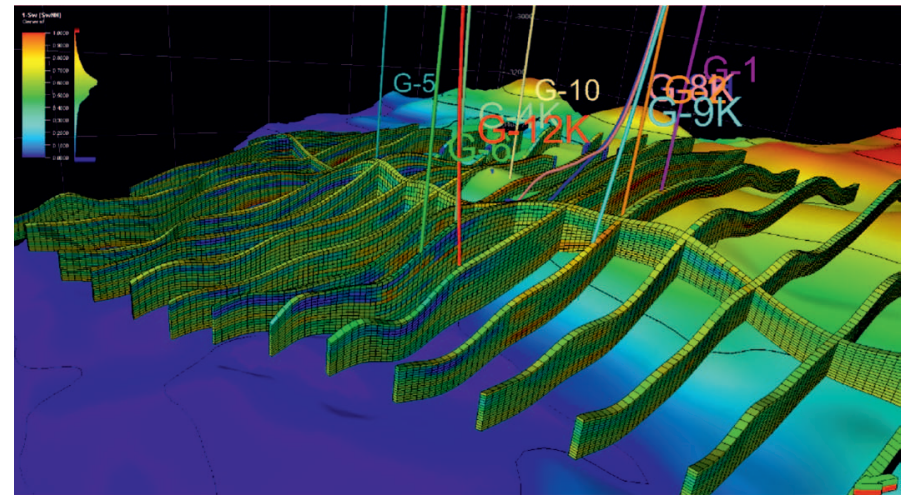

Rys. 22. Model nasycenia węglowodorami w obrębie analizowanego obszaru uwzględniający estymowane dane w otworach G-4K i G-12

Fig. 22. Hydrocarbon saturation model within analyzed area considering estimated values in boreholes G-4K and G-12

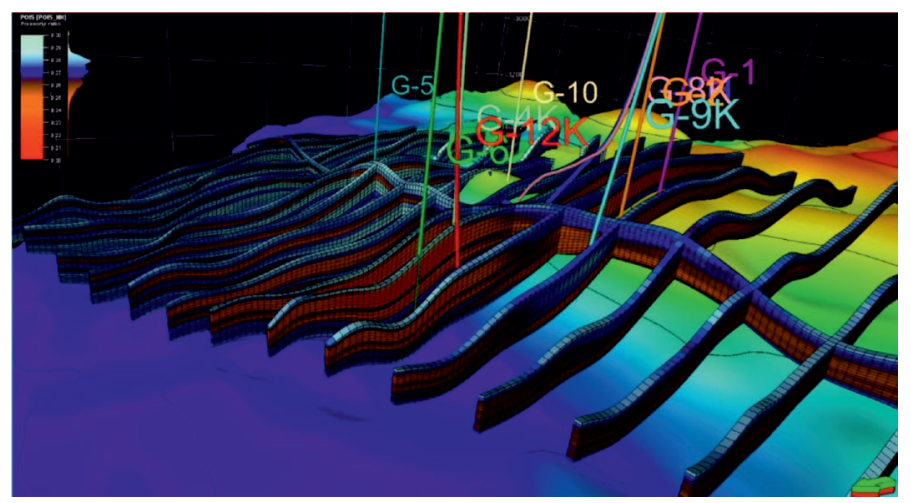

Rys. 24. Model współczynnika Poissona w obrębie analizowanego obszaru uwzględniający estymowane dane w otworach G-5, G-6 i G-8K

Fig. 24. Poisson ratio model within analyzed area considering estimated values in boreholes G-5, G-6 and G-8K

o brakujące interpretacje w profilach otworów wiertniczych. Zaprezentowana w pracy metodyka stanowi alternatywę dla wykonania indywidualnych interpretacji krzywych geofizyki wiertniczej, stanowiących najbardziej pożądaną informację

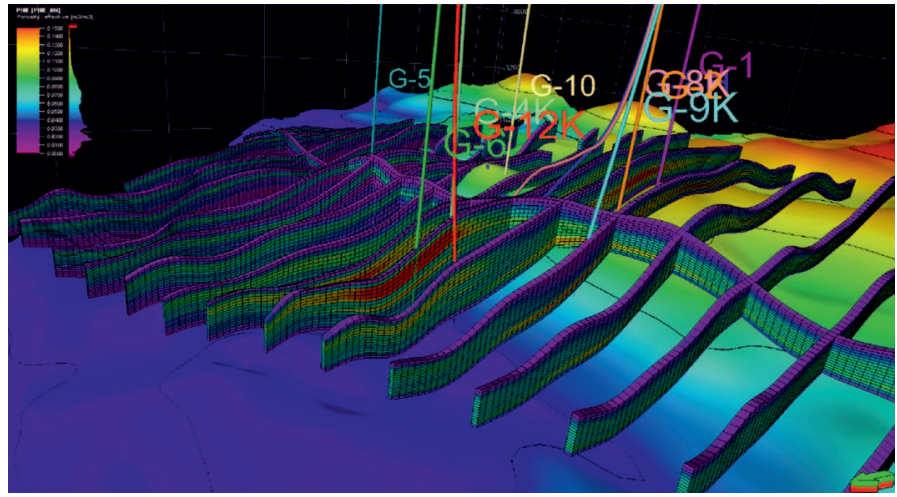

Rys. 21. Model porowatości efektywnej w obrębie analizowanego obszaru uwzględniający estymowane dane w otworach G-4K, G-10 i G-12

Fig. 21. Effective porosity model within analyzed area considering estimated values in boreholes G-4K, G-10 and G-12

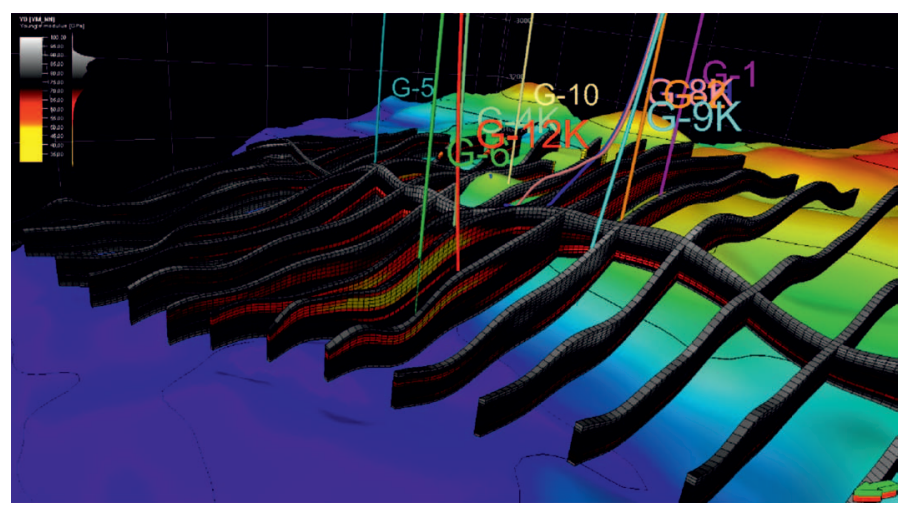

Rys. 23. Model modułu Younga w obrębie analizowanego obszaru uwzględniający estymowane dane w otworach G-5, G-6 i G-8K

Fig. 23. Young modulus model within analyzed area considering estimated values in boreholes G-5, G-6 and G-8K

otworową, kalibrowaną często wynikami badań laboratoryjnych. Wyniki zaprezentowane w artykule przybliżają jedynie rezultaty przeprowadzenia interpretacji otworowych danych geofizycznych, stanowiąc jednocześnie pośrednią informację wynikającą z zależności zaobserwowanych w pozostałych otworach wiertniczych, dla których estymowany parametr był dostępny.

Estymacji poddano pięć parametrów: Vs, PHIE, 1-Sw, YM, PR w profilach otworów, dla których były niedostępne. Podczas estymacji każdego z nich wykorzystywano jednakowy zestaw danych wejściowych, poddanych procesowi uczenia nadzorowanego parametrem, którego wartości dostępne były w pozostałych otworach. Wyniki poddane zostały walidacji poprzez obliczenie trzech parametrów: R, RMSE, NormRMSE, których wartości wahają się w szerokich zakresach w przypadku każdego z estymowanych parametrów w poszczególnych otworach. Wahania te wskazują na zmienność przestrzenną analizowanego obszaru, co zostało potwierdzone szeroko zakrojonymi badaniami laboratoryjnymi, o czym wspomniano w podrozdziale charakteryzującym krótko analizowany obszar. 
a)

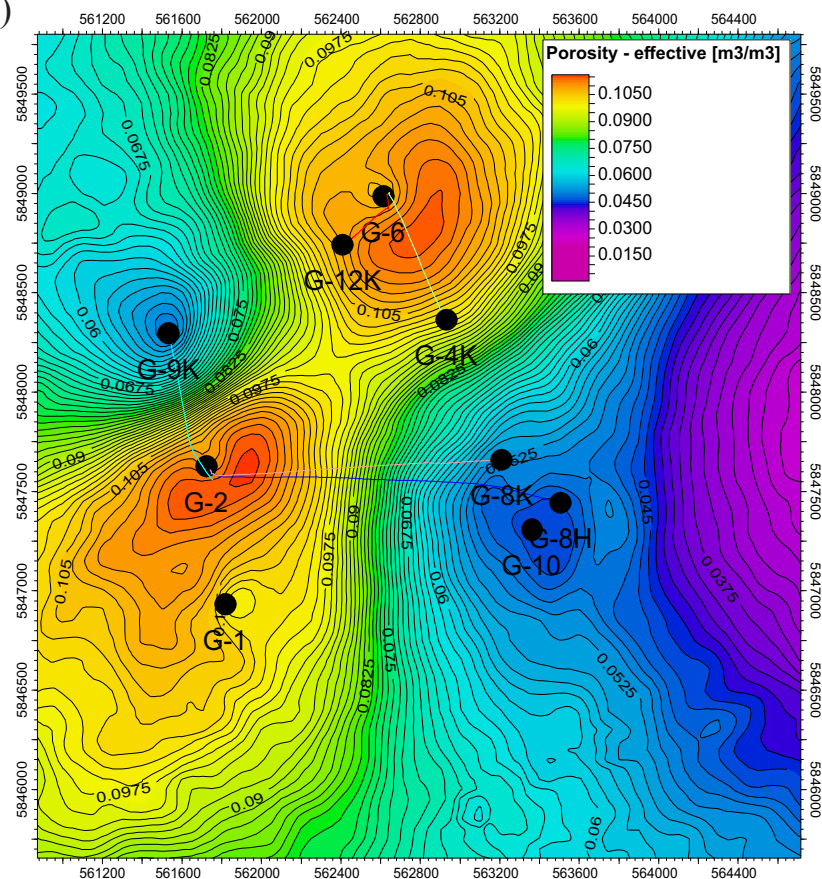

b)

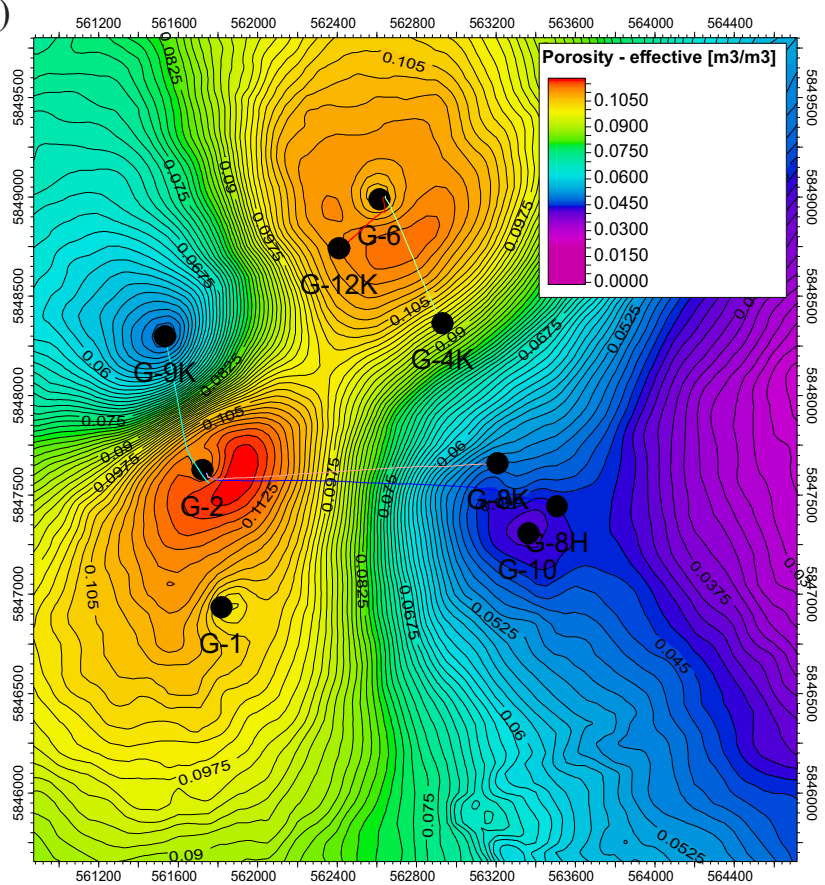

Rys. 25. Mapy średnich wartości porowatości efektywnej będących wynikiem modelowania: a) ograniczonego zestawu danych, b) pełnego (po części estymowanego) zestawu danych otworowych

Fig. 25. Map of effective porosity average values within analyzed interval resulting from modeling of a) a limited data set,

b) a full (partially estimated) set of borehole data

Zastosowanie zaprezentowanej w artykule procedury estymacji dodatkowych danych zwiększa prawdopodobieństwo uzyskania bardziej wiarygodnych wyników modelowania przestrzennego. Niemniej jednak istotne jest bardziej szczegółowe przeanalizowanie charakteru rozbieżności pomiędzy parametrami rzeczywistymi a estymowanymi (niedoszacowań i przeszacowań) i sposobu ich minimalizacji.

Współczynniki korelacji pomiędzy parametrami biorącymi udział w procesie uczenia a parametrem uczącym (estymowanym w profilach otworów, dla których nie był dostępny) przyjmowały różne wartości, sugerujące w pewnych przypadkach, że ich udział w procesie uczenia mógł zostać pominięty (słabe współczynniki korelacji, poniżej 0,5).

Biorąc pod uwagę przedstawiony w artykule zestaw danych, na których opierał się proces uczenia się sieci neuronowej, bazując na wynikach analizy parametrów R i RMSE, należy stwierdzić, że przedstawiona metoda najdokładniej przybliża wyniki estymacji parametru porowatości efektywnej. Parametr nasycenia węglowodorami również został poddany próbie estymacji sieciami neuronowymi, potwierdzając niskimi wartościami korelacji pomiędzy analizowanymi parametrami i najsłabszym odzwierciedleniem rzeczywistych pomiarów, że wymaga zdecydowanie bardziej zaawansowanych prac o indywidualnym charakterze.

Do realizacji badań wykorzystano oprogramowanie Petrel, którego licencją firma Schlumberger wsparła główną autorkę publikacji dla celu realizacji projektu doktorskiego.
Artykuł powstał na podstawie pracy statutowej pt. Sposoby prognozowania stref perspektywicznych w formacjach weglanowych o ograniczonych wtaściwościach filtracyjnych - praca INiG - PIB na zlecenie MNiSW; nr zlecenia: 0032/ SG/2019, nr archiwalny: DK-4100-0020/2020.

\section{Literatura}

Czekański E., Kwolek K., Mikołajewski Z., 2010. Złoża węglowodorów w utworach cechsztyńskiego dolomitu głównego (Ca2) na bloku Gorzowa. Przeglad Geologiczny, 58: 695-703.

Das V., Mukerji T., 2019. Petrophysical properties prediction from pre-stack seismic data using convolutional neural networks. Conference: SEG Technical Program Expanded Abstracts. DOI: 10.1190/segam2019-3215122.1.

Darłak B., Włodarczyk M., 2001. Zastosowanie sztucznej sieci neuronowej do uzupełnienia danych zbiornikowych. Przeglą Geologiczny, 49(9): 797-803.

Fajana A.O., 2020. 3-D static modelling of lateral heterogeneity using geostatistics and artificial neural network in reservoir characterisation of "P” field, Niger Delta. NRIAG Journal of Astronomy and Geophysics, 9(1): 129-154. DOI: 10.1080/20909977.2020.1727674.

Jarzyna J., Opyrchał A., Mozgowoj D., 2007. Sztuczne sieci neuronowe dla uzupełnienia danych w geofizyce otworowej - wybrane przykłady. Kwartalnik AGH Geologia, 33(4/1): 81-102.

Jaworowski K., Mikołajewski Z., 2007. Oil- and gas-bearing sediments of the Main Dolomite $(\mathrm{Ca} 2)$ in the Międzychód region: a depositional model and the problem of the boundary between the second and third depositional sequences in the Polish Zechstein Basin. Przeglad Geologiczny, 55: 1017-1024.

Kaźmierczuk M., Jarzyna J., Semyrka R., 2006. Wykorzystanie analizy składowych głównych do opracowania parametrów zbiornikowych w rejonie złóż Międzychód, Sieraków, Sowia Góra, 
Grotów i Lubiatów. Technika Poszukiwań Geologicznych, 2: 57-63.

Kohli A., Arora P., 2014. Application of Artificial Neural Networks for Well Logs. International Petroleum Technology Conference. DOI: 10.2523/IPTC-17475-MS

Krogulec E., Sawicka K., Zabłocki S., Falkowska E., 2020. Mineralogy and Permeability of Gas and Oil Dolomite Reservoirs of the Zechstein Main Dolomite Basin in the Lubiatów Deposit (Poland). Energies, 13: 6436. DOI: 10.3390/en13236436.

Kurenkov A., 2020. A Brief History of Neural Nets and Deep Learning. Skynet Today. https://skynettoday.com/overviews/ neural-net-history.

Kwolek K., Mikołajewski Z., 2010. Kryteria identyfikacji obiektów litofacjalnych jako potencjalnych pułapek złożowych w utworach dolomitu głównego (Ca2) u podnóża platform i mikroplatform węglanowych w środkowo-zachodniej Polsce. Przegląd Geologiczny, 58: 426-435.

Mikołajewski Z., 2004. Mikrofacje dolomitu głównego z wytypowanych obszarów badań. [W:] Wagner R., Kotarba M. (red.). Algowe skały macierzyste dolomitu głównego i ich potencjał węglowodorowy jako podstawa dla genetycznej oceny zasobów ropy naftowej i gazu ziemnego w strefie Gorzowa-Międzychodu. Narodowe Archiwum Geologiczne PIG-PIB, Warszawa.

Okon A.N., Adewole S.E., Uguma E.M., 2020. Artificial neural network model for reservoir petrophysical properties: porosity permeability and water saturation prediction. Modeling Earth Systems and Environment. DOI: 10.1007/s40808-020-01012-4.

Pham N., Wu X., Naeini E.Z., 2020. Missing well log prediction using convolutional long short-term memory network. Geophysics, 85(4): WA159-WA171. DOI: 10.1190/geo2019-0282.1.

Pikulski L., 2004. Analiza paleogeograficzna utworów dolomitu głównego (Ca2) w rejonie Lubiatów-Międzychód-Grotów w aspekcie poszukiwania złóż. Nafta-Gaz, 9: 397-405.

Puskarczyk E., 2019. Artificial neural networks as a tool for pattern recognition and electrofacies analysis in Polish palaeozoic shale gas formations. Acta Geophys., 67: 1991-2003. DOI: 10.1007/ s11600-019-00359-2.

Russakovsky O., Deng J., Su H., Krause J., Satheesh S., Ma S., Huang Z., Karpathy A., Khosla A., Bernstein M., Berg A.C., Fei-Fei L., 2015. ImageNet Large Scale Visual Recognition Challenge. International Journal of Computer Vision, 115(3): 211-252. DOI: 10.1007/s11263-015-0816-y.

Schmidhuber J., 2015. Deep learning in neural networks: An overview. Neural Networks, 61: 85-117. DOI: 10.1016/j.neunet.2014.09.003.

Semyrka R., Jarzyna J.A., Krakowska P.I., Semyrka G., 2015. Analiza statystyczna parametrów mikrofacji dolomitu głównego w granicznej strefie platformy węglanowej. Miner. Resour. Manag., 31: 123-140. DOI: 10.1515/gospo-2015-0011.

Semyrka R., Semyrka G., Zych I., 2008. Zmienność parametrów petrofizycznych subfacji dolomitu głównego zachodniej strefy półwyspu Grotowa w świetle badań porozymetrycznych. Geologia, 34: 445-468.

Słota-Valim M., 2018. Określanie mechanicznych właściwości skał na podstawie właściwości fizycznych przy użyciu sztucznych sieci neuronowych. Nafta-Gaz, 5: 343-355. DOI: 10.18668/ NG.2018.05.01.
Sowiżdżał K., 2013. Geologiczne, przestrzenne modelowanie złóż węglowodorów - aspekty metodyczne i przykłady zastosowań. Prace Naukowe Instytutu Nafty i Gazu - Państwowego Instytutu Badawczego, 192: 101-111.

Tadeusiewicz R., Haduch B., 2015. Wykorzystanie sieci neuronowych do analizy danych i pozyskiwania wiedzy w systemie ekspertowym do oceny parametrów benzyn silnikowych. Nafta-Gaz, 10: 776-785.

Tadeusiewicz R., Szaleniec M., 2015. Leksykon sieci neuronowych. Wydawnictwo Fundacji „Projekt Nauka”. ISBN: 978-83-63270-10-0.

Topór T., 2020. An integrated workflow for MICP-based rock typing: A case study of a tight gas sandstone reservoir in the Baltic Basin (Poland). Nafta-Gaz, 4: 219-229. DOI: 10.18668/NG.2020.04.01

Topór T., 2021. Application of machine learning algorithms to predict permeability in tight sandstone formations. Nafta-Gaz, 5: 3-12. DOI: $10.18668 /$ NG.2021.05.

Wagner R., 2004. Mapa paleogeograficzna dolomitu głównego (Ca2) - Półwysep Grotowa. [W:] Wagner R., Kotarba M. (red.). Algowe skały macierzyste dolomitu głównego i ich potencjał węglowodorowy jako podstawa dla genetycznej oceny zasobów ropy naftowej i gazu ziemnego w strefie Gorzowa-Międzychodu. Narodowe Archiwum Geologiczne PIG-PIB, Warszawa.

Wawrzyniak-Guz K., Krakowska P., Puskarczyk E., Jarzyna J., 2016. Wyznaczenie elektrofacji w sweet spotach sylursko-ordowickich formacji łupkowych z rejonu basenu bałtyckiego na podstawie profilowań geofizyki otworowej z zastosowaniem samoorganizujących się sieci neuronowych. Prace Naukowe Instytutu Nafty i Gazu - Państwowego Instytutu Badawczego, 209: 589-593.

Zare A., Bagheri M., Ebadi M., 2020. Reservoir facies and porosity modeling using seismic data and well logs by geostatistical simulation in an oil field. Carbonates Evaporites, 35(65). DOI: 10.1007/s13146-020-00605-5.

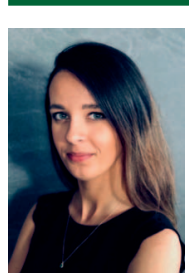

Mgr inż. Weronika KACZMARCZYK-KUSZPIT Asystent w Zakładzie Geologii i Geochemii Instytut Nafty i Gazu - Państwowy Instytut Badawczy ul. Lubicz $25 \mathrm{~A}$

31-503 Kraków

E-mail: weronika.kaczmarczyk@inig.pl

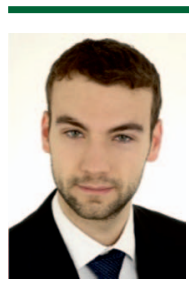

Mgr inż. Andrzej BRODZICKI

Laboratorium Systemów Wizyjnych, Katedra Automatyki i Robotyki, Wydział Elektrotechniki, Automatyki, Informatyki i Inżynierii Biomedycznej Akademia Górniczo-Hutnicza im. St. Staszica w Krakowie

Al. Mickiewicza 30, 30-059 Kraków E-mail: brodzicki@agh.edu.pl 